\title{
Water Quality and
}

Discharge of Streams in the Lehigh River Basin, Pennsylvania

GEOLOGICAL SURVEY WATER-SUPPLY PAPER 1879-H

Prepared in cooperation with the Commonwealth of Pennsylvania Department of Forests and Waters

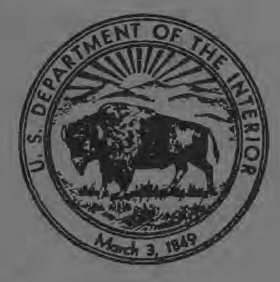




\section{Water Quality and}

\section{Discharge of Streams in}

\section{the Lehigh River Basin,}

\section{Pennsylvania}

By EDWARD F. MCCARREN and WALTER B. KEIGHTON

CONTRIBUTIONS TO THE HYDROLOGY OF THE UNITED STATES

GEOLOGICAL SURVEY WATER-SUPPLY PAPER 1879-H

Prepared in cooperation with the Commonwealth of Pennsylvania Department of Forests and Waters

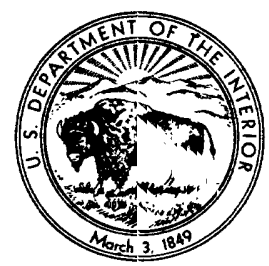




\title{
UNITED STATES DEPARTMENT OF THE INTERIOR
}

WALTER J. HIGKEL, Secretary

\author{
GEOLOGICAL SURVEY
}

William T. Pecora, Director 


\section{CONTENTS}

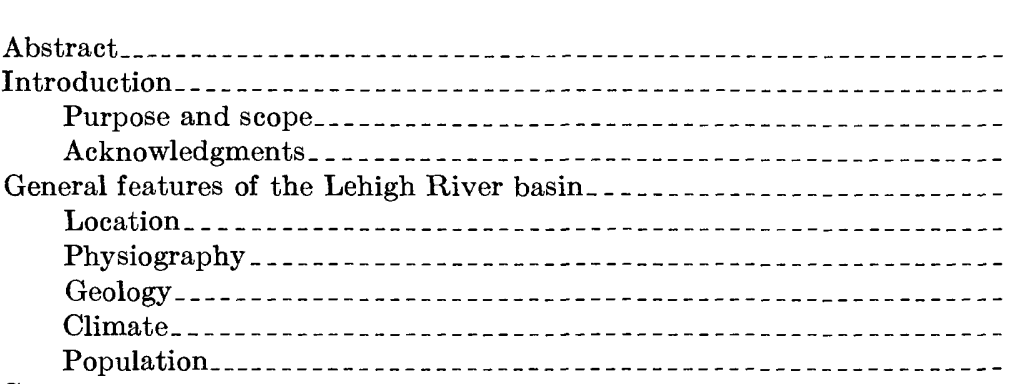

Reservoirs _...

Water quality of streams

Chemical quality of headwater streams draining the Appalachian Plateaus

Lehigh River at Stoddartsville

Tobyhanna and Tunkhannock Creeks

Bear Creek .

Lehigh River at White Haven and Lehigh Tannery .......... 14

Dilldown Creek . . .

$\begin{array}{ll}\text { Chemical quality of streams draining the Valley and Ridge province } & 14\end{array}$

Acid-bearing streams-Sandy and Indian Runs and Pond, Quakake, Black, and Nesquehoning Creeks.............. Alkaline-type streams-Mahoning, Pohopoco, Lizard, and Aquashicola Creeks

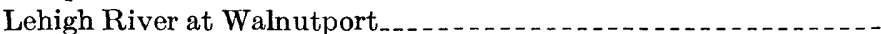

Other streams in the Valley and Ridge province-Little Lehigh, Monocacy, Coplay, Cedar, and Jordan Creeks...............

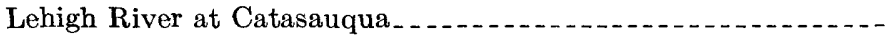

Chemical quality of streams draining the New England province......

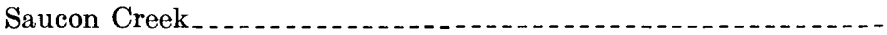

Lehigh River at Bethlehem and Glendon............... 19

Lehigh River at Easton. . .

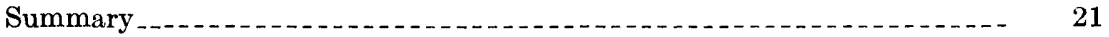

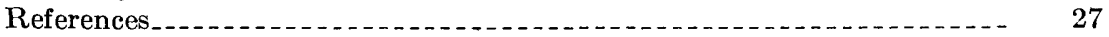

\section{ILLUSTRATIONS}

FIGURE 1. Map showing physiographic provinces and location of water-quality sampling sites...........................

2. Map showing geology and stream quality ............ 6

3-11. Graphs:

3. Water-temperature variations with depth, Francis

E. Walter Reservoir, June 16 and 29, 1966..... 
Figures 3-11. Graphs-Continued

4. Dilution effects of water released from Francis E. Walter Reservoir, Lehigh River at Easton, June 20-30, 1966

5. Relation of dissolved solids and calcium and magnesium hardness to specific conductanee, Lehigh River at Catasauqua, 1944-53.

6. Relation of dissolved solids, calcium, bisarbonate, and sulfate to specific conductance, Lehigh River at Bethlehem, 1959-66

7. Cumulative frequency curve of specific conductance, Lehigh River at Glendon, 1956-58

8. Cumulative frequency curve of specific conductance, Lehigh River at Easton, October 1962 to September 1966

9. Graph showing relationship between dissolved solids and specific conductance, Lehigh River at Easton, 1961-66.

10. Cumulative frequency curve of water temperature, Lehigh River at Easton, October 1962 to September 1965.

11. Graph showing daily maximum and minimum, and monthly averages of, water temperature, Lehigh River at Easton, October 1962 to September 1966

\section{TABLES}

TABLE 1. Water quality data, Lehigh River at Easton, June 1-30,

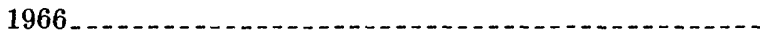

2. Maximum and minimum values of physical an properties, Lehigh River at Catasauqua, 1944-53.......

3. Given values of physical and chemical prop?rties that were equaled or exceeded for indicated percent of days, Lehigh River at Catasauqua, 1945-52

4. Daily specific conductance, Lehigh River s.t Easton, October 1965 to September $1966 \ldots \ldots$. . . . . . . . . . .

5. Continuous recording of water quality by instrument, Lehigh River at Easton, May 1966 to April 1967

6. Chemical analyses of streams in the Lehigh River basin, 1944-67 


\title{
CONTRIBUTIONS TO THE HYDROLOGY OF THE UNITED STATES
}

\section{WATER QUALITY AND DISGHARGE OF STREAMS IN THE LEHIGH RIVER BASIN, PENNSYLVANIA}

\author{
By Edward F. McCarren and Walter B. Keighton
}

\section{ABSTRACT}

The Lehigh River, 100 miles long, is the second largest tributary to the $\mathrm{D}$ slaware River. It drains 1,364 square miles in four physiographic provinces. The Lehigh River basin includes mountainous and forested areas, broad agricultural valleys and areas of urban and industrial development. In the headwaters the rater is of good quality and has a low concentration of solutes. Downstream, some tributaries receive coal-mine drainage and become acidic; others drain areas underlain by limestone and acquire alkaline characteristics. The alkaline streams neutralize and dilute the acid mine water where they mix. The dissolved-oxygen content of river water, which is high in the upper reaches of the str $3 a m$, is reduced in the lower reaches because of lower turbulence, higher temperature, and the respiration of organisms. The Lehigh is used for public supply, recreation, waterpower, irrigation, and mining and other industrial purposes.

Because the river is shallow in its upper reaches, most of the water comes in contact with the atmosphere as it churns over rocks and around islets ard large boulders. Aeration of the water is rapid. When water that was low in dirsolvedoxygen concentration was released from the lower strata of the Francis E. Walter Reservoir in June 1966, it quickly became aerated in the Lehigh River, and for 40 miles downstream from the dam the water was nearly saturated with oxygen.

Most of the river water requires only moderate treatment for industrial use and public distribution throughout the Lehigh River valley. At times, however, some segments of the main river and its tributaries transport industrial wastes and acid coal-mine drainage. Usually the relatively high concentrations of solutes in water and the ensuing damage caused to quality by such waste dis?harges are more extensive and prolonged during droughts and other periods of low streamflow.

For many years the Lehigh River flow has been continuously measured and its waters chemically analyzed. Since May 1966 an instrument installed by the U.S. Geological Survey at Easton, Pa., has continuously recorded such waterquality parameters as specific conductance, temperature, and dissolved oxygen content.

\section{INTRODUCTION}

The chemical characteristics of perennial streams that drain the Lehigh River basin in eastern Pennsylvania are described in this report. From selected locations throughout the drainage basin, samples of surface water have been taken systematically since 1944 and analyzed for the minerals that most commonly dissolve in water. Samples from some places were taken intermittently, sometimes only during high or low streamflow. At several selected locations 
samples were taken on consecutive days for durations of 1 year or more, and it was thus possible to observe those conditions that cause variations in water quality in terms of time and place.

Water is an indispensable ingredient of life. In its liquid and mobile state it is nature's most common solvent. As precipitation falling through the atmosphere it absorbs gases and picks up salt, dust, bacteria, spores, and other particles. Water flowing over and into the earth acquires materials in solution or suspension and transports them from place to place. In the atmosphere water is relatively low in solute content, and when it reaches the earth as precipitation in some form, it normally dilutes the water flowing in surface streams or that which lies in reservoirs, lakes, and ponds.

When there has been no precipitation, the water that maintains flow in streams issues from the ground. Ground water normally has more materials in solution than does surface water because it has been in contact with soluble rock longer. Consequently, additional solutes are introduced to streams by ground-water seepages, and during low flow streams reach their maximum concentration of dissolved solids.

Under normal conditions the quality of streams in the basin represents a mixture of ground water and runoff. In most streams domination of one source over the other is obvious during high and low discharges. The chemical composition of streams in the Lehigh River basin is also influenced by the particular geoloric formations through which ground water has moved.

Civilization has also affected the quality of some streams in the basin by allowing industrial wastes to enter them. Particularly damaging are those that come from coal mines because they are usually acid and contain high concentrations of dissolved solids.

In the present study quantitative determinations by chemical analysis were made for silica, aluminum, iron, mangenese, calcium, magnesium, sodium, potassium, carbonate, bicarbonate, sulfate, chloride, fluoride, nitrate, and dissolved solids as residue on evaporation at $180^{\circ} \mathrm{C}$. Color, $\mathrm{pH}$, and specific conductance were also determined. Acidity (as $\mathrm{H}_{2} \mathrm{SO}_{4}$ ) was determined on water samples with a $\mathrm{pH}$ below 4.5 and on those that were suspected of bearing coal-mine wastes.

Specific conductance (the ability of water to conduct electricity) is a characteristic of water that is used extensively in this study as the criterion of the quality of stream water at selected places. Pure water does not conduct electricity well. The resistance of pure water to the flow of an electric current diminishes with increasing concentrations of dissolved salts in water. The unit used to measure this resistance is the ohm; the unit of measure for the specific conductance is the reciprocal ohm, or mho. Most natural waters have diss ociated ions in 
concentrations of less than 1 mho; therefore specific conductance is usually reported in micromhos (millionths of a mho).

The $\mathrm{pH}$ indicates the acidity or alkalinity of the water. $\mathrm{A} \mathrm{pH}$ value of 7.0 indicates a neutral water; lower $\mathrm{pH}$ values are acid and higher $\mathrm{pH}$ values are alkaline. Most stream waters have a $\mathrm{pH}$ betweer 5 and 8 , but acid mine waters frequently have a $\mathrm{pH}$ of $2-4$. Acid waters are often corrosive and costly to treat for general usage.

This study was carried out jointly by the Pennsylvania Department of Forests and Waters and the U.S. Geological Survey. Many of the data on the chemical quality of water in the Lehigh River basin interpreted here appear in table 6 . Some of the analytical data have been published previously in U.S. Geological Survey Water-Supply Papers "Quality of Surface Waters of the United States," Parts 1-4, and some have been published in "Water Quality Records in Pennsylrania," which was prepared in cooperation with the Commonweslth of Pennsylvania and other agencies.

\section{PURPOSE AND SCOPE}

The purpose of this investigation is to present a useful organization of the chemical analyses of stream waters in the Lehigh River drainage system. Wherever possible, the environmental factors that significantly influence stream quality at different places throughout the basin are also identified. This quality appraisal relies solely on the basic data obtained from the continuing studies conducted cooperatively by State and Federal agencies.

\section{ACKNOWLEDGMENTS}

This report was written under the general supervision of Norman $H$. Beamer, district chief, of Pennsylvania Water Resources Division, U.S. Geological Survey. The authors acknowledge with appreciation the cooperation of the U.S. Weather Bureau and the U.S. Army Corps of Engineers, Philadelphia district, during the quality investigations of the impounded water in the Francis E. Walter Reservoir. They also especially acknowledge the significant contributions made by Peter W. Anderson, chemist, during the initial stages of this study.

\section{GENERAL FEA'TURES OF THE LEHIGH RIVER BASIN}

\section{LOCATION}

The Lehigh River, in east-central Pennsylvania, flows southeastward into the Delaware River. It rises in Sterling Township in southwestern Wayne County and drains 1,364 square miles in all or parts of Wayne, Lackawanna, Monroe, Luzerne, Carbon, Schuylkill, Lehigh, Berks, Bucks, and Northampton Counties (fig. 1). It is one of three major tributaries to the Delaware, and its drainage is entirely within the boundaries of Pennsylvania. The other two tributaries are the Schuylkill River, the largest, and the Lackawaxen River. The mouth of the 
Lehigh is at Easton, in Northampton County, where the stream contributes approximately 21 percent of the average discharge of the Delaware River.

\section{PHYSIOGRAPHY}

The Lehigh River drains four physiographic provinces (Parker and others, 1964). In its headwaters above Jim Thorpe and East Mauch Chunk, the main river and several of its eastern tributaries drain the

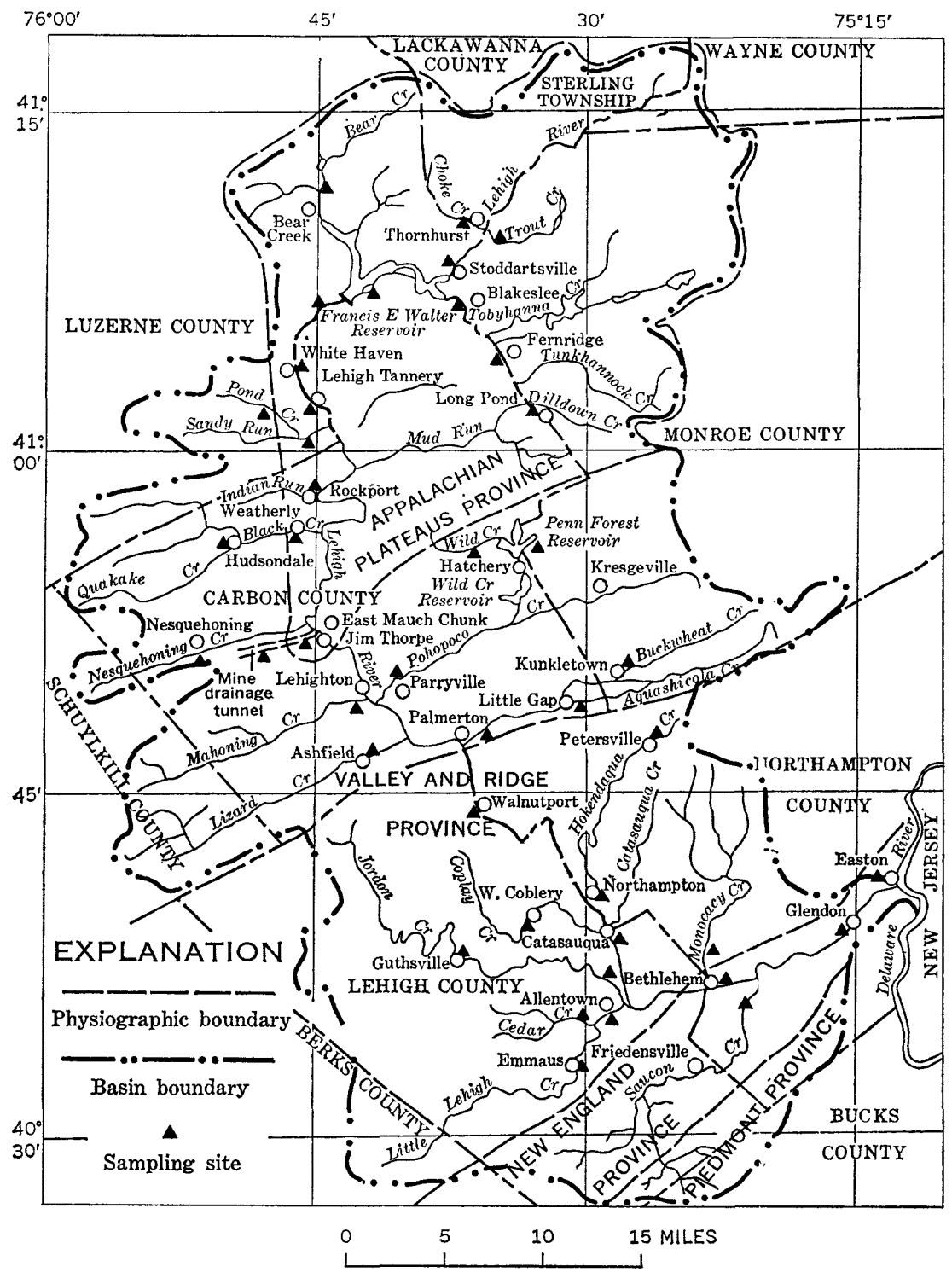

FIGURE 1.-Physiographic provinces and location of water-quality sampling sites. 
Appalachian Plateaus province (fig. 1). This area is rough, mountainous, and heavily forested, with many lakes, ponds, and swamps of glacial origin. Intense Pleistocene glaciation left extensive glacial-drift deposits throughout the entire area. The character and thickness of deposits differ considerably from place to place (Lohman, 1937).

Between White Haven and Allentown the western tributaries of the Lehigh, and some of those on the east, drain mostly the Valley and Ridge province. This province is also rough, mountainous, and well wooded. However, the ridges are lower and the intervening valleys broader. This area is more populated than the Appalachian Plateaus area, and there is more industrial and agricultural activity.

Below Allentown the Lehigh River and its southern tributaries drain the New England province and a very small part of the Piedmont province. The area consists of broad rounded uplands and deep narrow valleys. In the New England province are the industrial cities of Bethlehem and Easton; there is also considerable agricultural activity in the general area.

\section{GEOLOGY}

The Lehigh basin above Jim Thorpe is underlain by the Catskill Formation and the Pocono and Mauch Chunk Formations, which consist of shale, sandstone, and conglomerate (fig. 2). Most of the consolidated rocks are covered by glacial deposits of nonuniform thickness. Several small tributaries in the northwestern part of the basin drain the area underlain by the Pottsville and Allegheny Formations, which also consist of shale, sandstone, and conglomerate but contain coal deposits. The lower half of the basin, in the Valley and Ridge, New England, and Piedmont provinces, is underlain by shale, slate, sandstone, and limestone and other carbonate rocks. The ground water that seeps into streams from the carbonate rocks is alkaline and capable of neutralizing some of the acid coal-mine waste that enters the Lehigh above Lehighton.

\section{CLIMATE}

Mean annual precipitation in the Lehigh River basin ranges from 42 inches at Bethlehem to 48 inches at East Mauch Chunk and averages about 45 inches for the basin (1931-60). The lowest monthly average, 2.6 inches, normally occurs in February, and the highest monthly average, 4.9 inches, in July. Mean annual air temperature is $8^{\circ}$ Celsius in the headwaters and $11^{\circ} \mathrm{C}$ near Allentown and ranges from an average low of $-2^{\circ} \mathrm{C}$ in winter to an average high of $22^{\circ} \mathrm{C}$ in summer (U.S. Weather Bureau, 1964).

The combination of lakes, forests, cool summer temperatures, and proximity to the heavily populated cities of New York and Philadelphia makes this area a very popular tourist and recreation attraction. Mountainous terrain and heavy snowfalls also make it an attractive winter resort. 


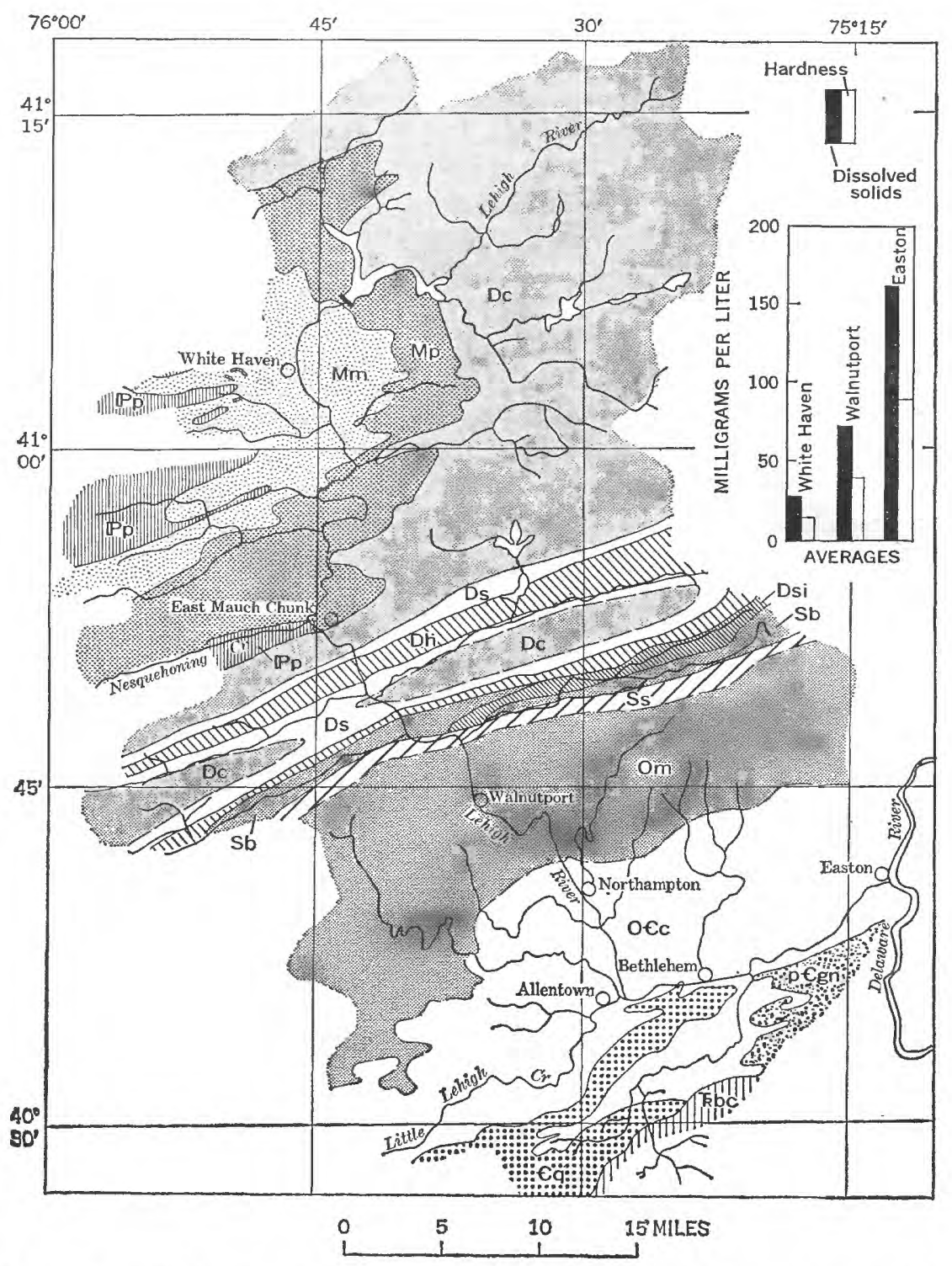

Figure 2.-Geology and stream quality. Geology from Parker and others (1964).

\section{POPULATION}

At the time of the 1960 census slightly more than 434,000 persons lived in the Lehigh River drainage area. Almost 60 percent of them lived in the industrial Allentown-Bethlehem-Easton complex near the river mouth. The remainder resided either in small communities centered around coal mining or light industries, in trading centers, or in rural areas. In 1964 population for the same area was estimated at 


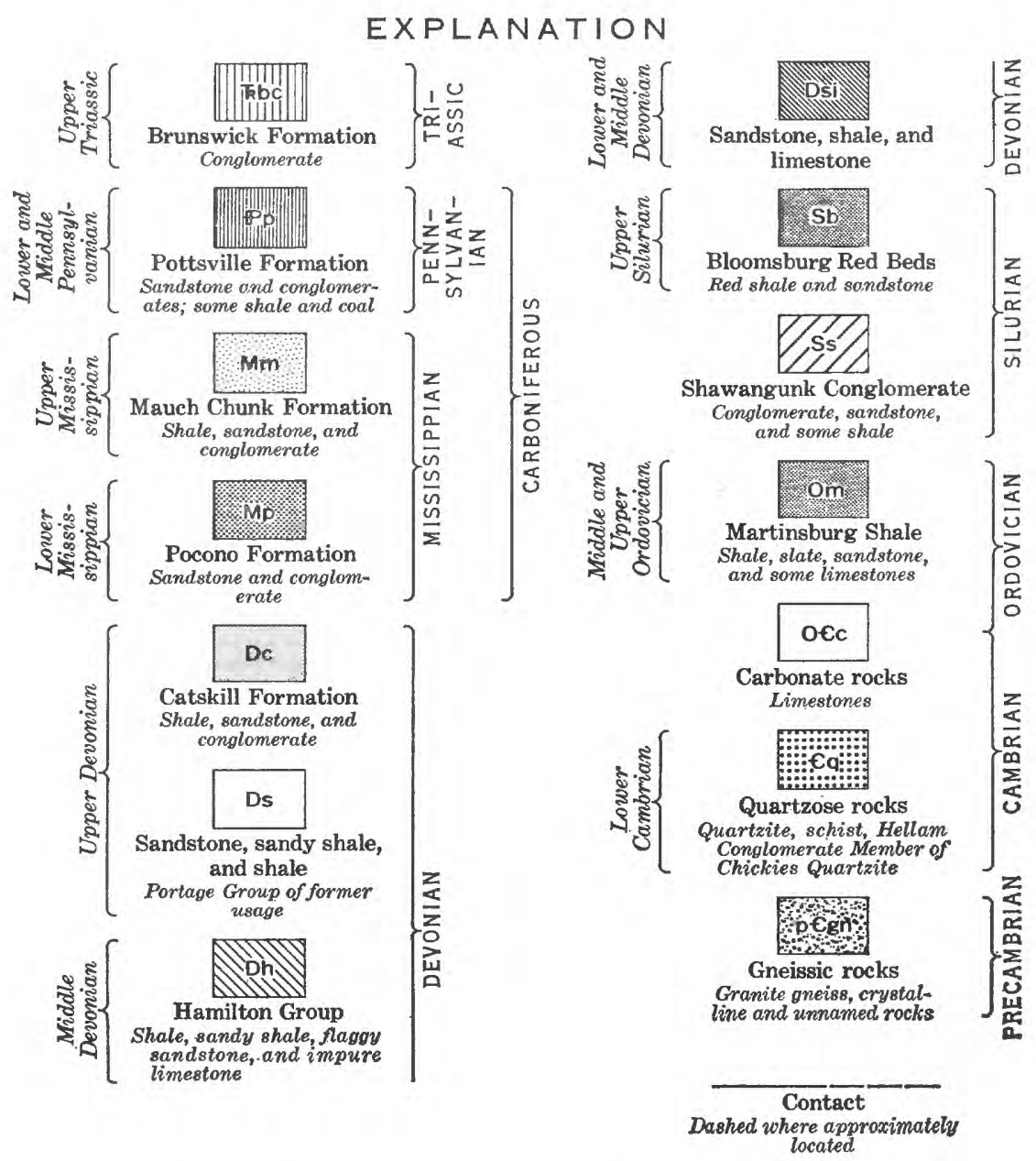

446,000 . By 1970 it is expected to increase to 465,000 (Delaware River Basin Commission, oral commun., 1965).

\section{COAL MINING}

Several streams, such as Sandy Run, Pond Creek, Indian Run, and Quakake, Black, and Nesquehoning Creeks, are affected by acidic wastes that issue from both active and abandoned coal mines. Some acid mine water also flows in to the Lehigh River from abandoned mines in the adjoining Schuylkill River basin by way of the Nesquehoning drainage tunnel. In March 1965 this drainage tunnel discharged wastes into the Lehigh that contained $965 \mathrm{mg} / \mathrm{l}$ (milligrams per liter) sulfate (table 6, p. H33). The tunnel discharge enters the Lehigh below Nesquehoning Creek and between East Mauch Chunk and Jim Thorpe. 
Mine water usually contains sulfuric acid because of reactions of water and air with sulfur compounds associated with coal deposits. Pyrite $\left(\mathrm{FeS}_{2}\right)$, the most common sulfide mineral, has an approximate chemical composition of 46 percent iron and 53 percent sulfur. Oxidation of pyrite, and its unstable isomer marcasite, is the underlying cause of acid mine drainage pollution of affected streams in Pennsylvania. Some streambeds in the Lehigh River basin, such as a tributary to Quakake Creek and Indian Run, are coated with deposits of iron compounds introduced by mine water.

Sulfuric acid in some tributary streams excludes many forms of aquatic plant life and makes the water corrosive to metals and concrete. In contact with rocks, acid-bearing water takes into solution more dissolved solids, including such generally undesirable metal ions as aluminum, iron, and manganese. These metal ions impart objectionable taste and staining to water and commonly add to the cost of water treatment. Mine water may also kill fish and many of the aquatic organisms on which fish feed (California State Water Pollution Control Board, 1963).

Unaffected natural water from other streams, mostly from the east, is either low in solute concentration or has alkaline characteristics that help to dilute or neutralize the waste-bearing streams where the two streams mix. Although fish kills caused by mine water and other industrial discharges into the river have been reported on numerous occasions, pollution by acid-mine drainage into the Lehigh has had negligible effects on fish populations at Easton. In the lower basin, near Allentown and Bethlehem, the following species of fish are reported to be in the river: Channel catfish, smallmouth and largemouth bass, sucker, bullhead, eel, and fallfish. In the headwaters above Lehigh Tannery to the mouth of Choke Creek, the Lehigh is also stocked with brown and rainbow trout, as are several other tributary streams in the Pocono Mountain regions of Monroe and Carbon Counties (Pennsylvania Fish Commission 1969).

\section{RESERVOIRS}

The Lehigh River valley has experienced many severe floods that have cost lives and millions of dollars in property damage. The rugged terrain and steep slopes in the headwaters of the basin direct rapid runoff in to the mainstream. The most recent damaging flood, in August 1955, was caused by the tropical storms Connie and Diane. At 10:00 a.m. August 19, 1955, the Lehigh River at Bethlehem was discharging water at 91,300 cfs (cubic feet per second) (Busch and Shaw, 1960). This is 40 times the average flow of the river and eight times the average flow of the Delaware River at Trenton, N.J.

To help protect the valley from future flood damage, the Francis E. Walter Reservoir was built on the main river a short distance below the mouth of Bear Creek. The reservoir was completed in 1961 
and was designed primarily for flood control, but proposed structural modifications will make it serviceable for long-term storage, recreation, and water supply.

A multiple-purpose reservoir will be bullt on Aquashicola Creek, which drains parts of Monroe and Carbon Counties. The d $\varepsilon \mathrm{m}$ site will be 4.5 miles upstream from the confluence of the creek with the Lehigh River. The Beltzville Reservoir will be built for multiple purposes on Pohopoco Creek about 4 miles east of Lehighton. The Beltzville Reservoir and a reservoir to be built on Jordan Creek in Lehigh County will be designed to prevent flood damage and to provide storage of water for recreation and supply.

On Wild Creek, tributary to Pohopoco Creek in Carbon County, the Penn Forest Reservoir, 0.7 mile upstream from Hatchery, is used as a municipal water supply for the city of Bethlehem. Wild Creek Reservoir, 2.4 miles south of Hatchery, is also used as a water supply for Bethlehem. Levees and other projects for flood protection have been completed on the river at Allentown and Bethlehem (U.S. Army Corps of Engineers, 1967).

The Francis E. Walter Reservoir is in the headwaters of the Lehigh River and impounds natural water of excellent quality (McCarren and Keighton, 1967). In June 1966 the Delaware River Basin Commission requested the release of water from the reservoir so that more space could be made available for the storage of excessive runoff resulting from potentially severe seasonal storms. Accordingly, the U.S. Army Corps of Engineers released approximately 11 billion gallons of impounded water to the Lehigh June 20-27 at a rate of approximately $3,000 \mathrm{cfs}$, or 1.3 million gallons per minute. Observations of the quality of water in the reservoir and in the river at selected locations were made before, during, and after the release.

Water temperature in the reservoir decreased with depth; before the releases the water temperature in the upper 5 feet of the raservoir was $19^{\circ} \mathrm{C}$, at 50 -foot depth $15^{\circ} \mathrm{C}$, and at 100 -foot depth $14^{\circ} \mathrm{C}$ (fig. 3). Since oxygen is consumed by chemical reactions in stored water and is commonly replaced by aeration at the surface, it is likely that there was a deficiency in dissolved oxygen at depth, although this was not verified. The water entering the reservoir from Bear and Tobyhanna Creeks and from the Lehigh River was of excellent quality- $\mathrm{pH}$ 5.3-7.1 and specific conductance 22-57 micromhos (table 6, p. H30-H31). Water was released from the reservoir June 20-27 from an outlet 140 feet below the surface. The relatively cool water released through this outlet reduced stream temperatures. Cooling effects on river rater at Easton were as much as $2^{\circ} \mathrm{C}$. The water became warmer dowastream from the reservoir as it came in contact with warm air; on June 21 river water at White Haven was $4^{\circ} \mathrm{C}$ warmer $\left(17^{\circ} \mathrm{C}\right)$ than the water released from the reservoir June 20. 


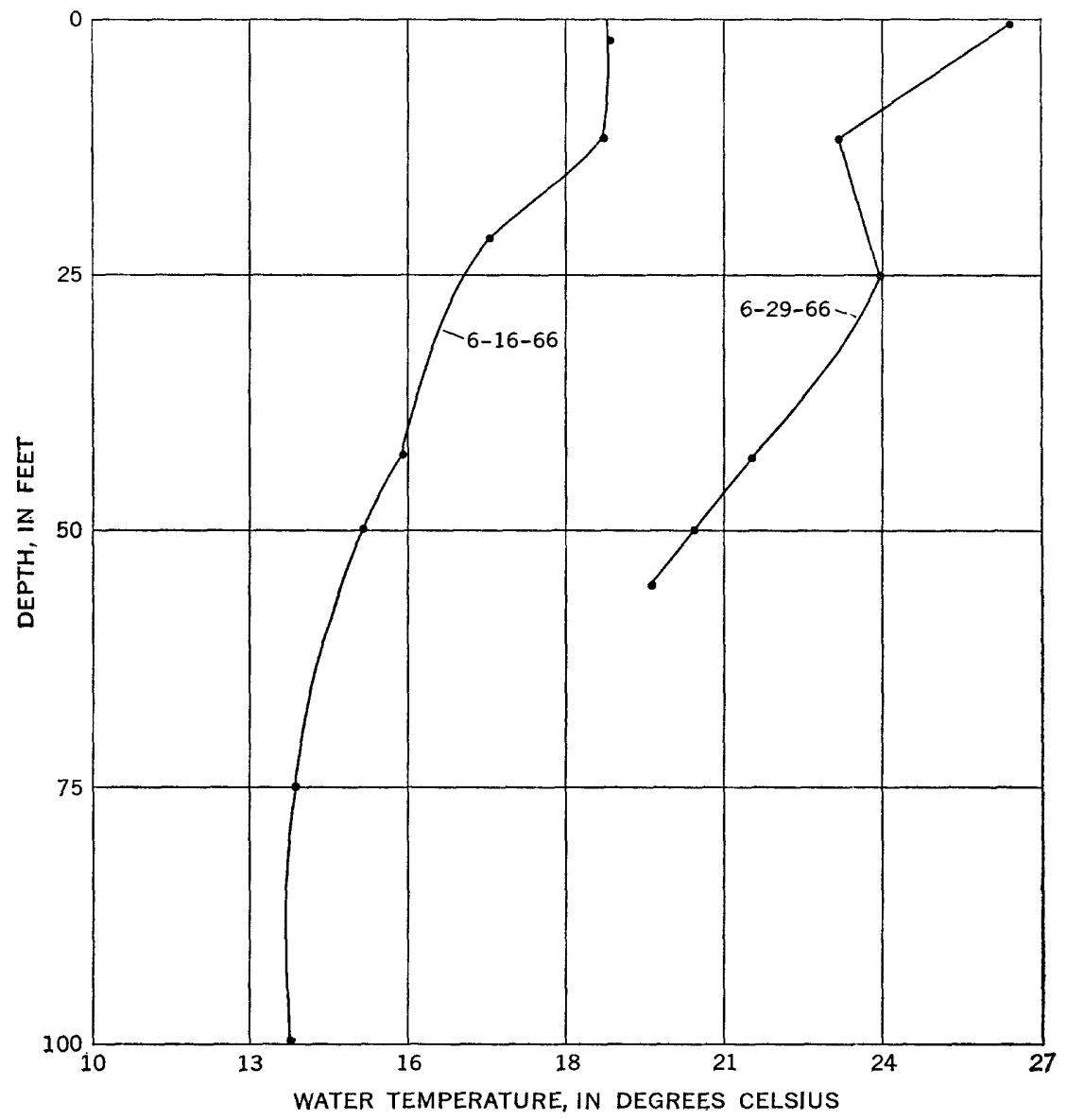

FIGURE 3.-Water-temperature variations with depth, Francis E. Walter Reservoir, June 16 and 29, 1966.

River water was diluted by the reservoir water, and its quality was improved, as shown by the decrease in specific conductance as far as Easton. Within 2 days specific conductance at Easton dropped from 232 to 100 micromhos (fig. 4 and table 1 ).

Although the water at depth in the reservoir probably was deficient in oxygen, the dissolved-oxygen concentration of the river water did not decrease when the reservoir water was released. This was probably because the Lehigh River is shallow and rockstrewn for some miles below the reservoir. The increased flow resulted in turkulence which provided an opportunity for mechanical aeration of the water. Since the temperature was lower, the water had a greater capacity to dissolve oxygen. Consequently, the dissolved-oxygen concentrotion of river water at Easton actually increased. For the 5 days preceding the release the average dissolved-oxygen concentration at Easton was $5.3 \mathrm{mg} / \mathrm{l}$, and for 5 days during the release (June 22-26) it was $6.5 \mathrm{mg} / \mathrm{l}$ (table 1 ). 
O.Gट $\perp \forall$ \&

SOHWOYJIW NI "JJNYIONANOJ JHIOJdS

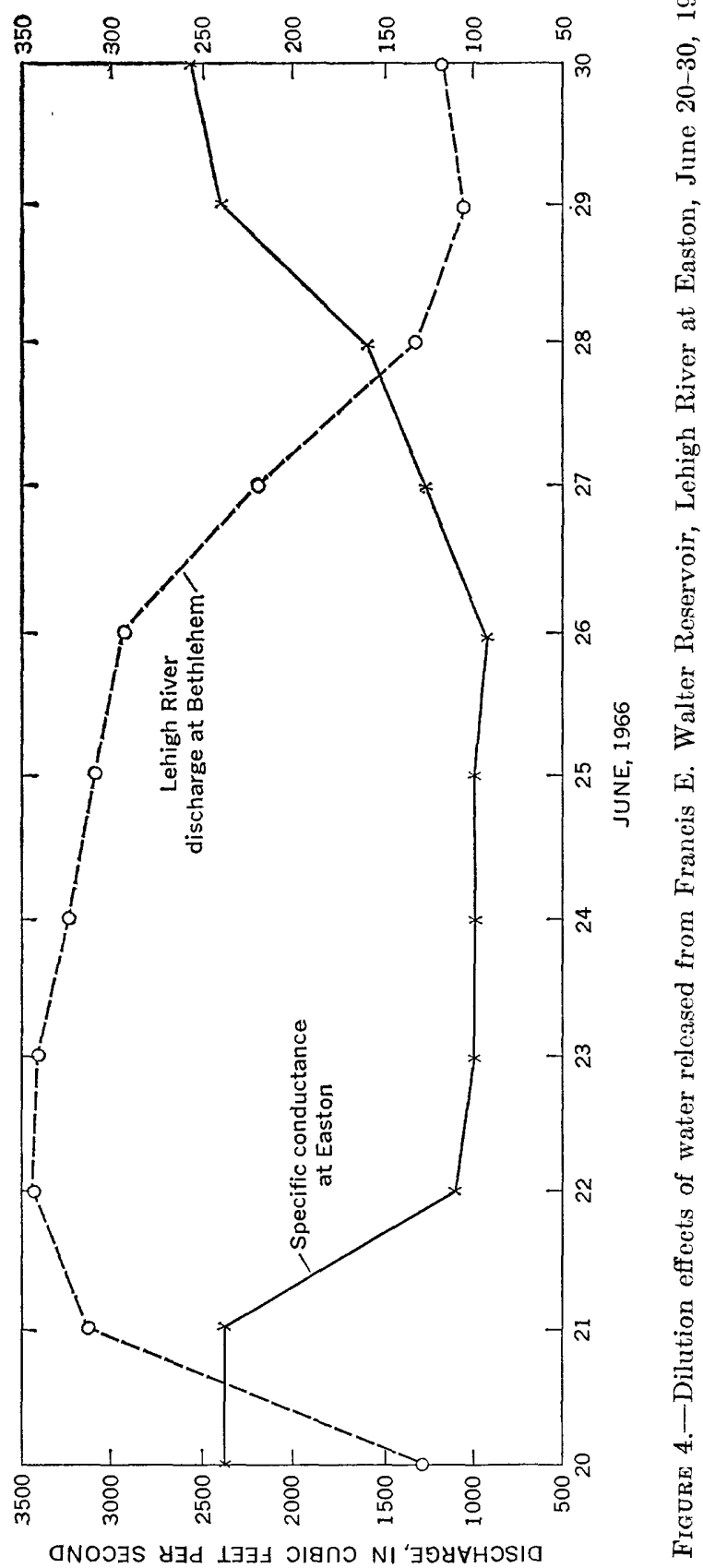


TABLE 1.-Water quality data, Lehigh River at Easton, June 1-30, 1966

\begin{tabular}{|c|c|c|c|c|c|c|c|c|}
\hline \multirow{3}{*}{$\begin{array}{l}\text { Date } \\
\text { (June } \\
\text { 1966) }\end{array}$} & \multirow{2}{*}{\multicolumn{2}{|c|}{ Temperature $\left({ }^{\circ} \mathrm{C}\right)$}} & \multicolumn{4}{|c|}{ Dissolved oxygen } & \multirow{2}{*}{\multicolumn{2}{|c|}{$\begin{array}{l}\text { Specific conductance } \\
\text { (micromhos at } 25^{\circ} \mathrm{C} \text { ) }\end{array}$}} \\
\hline & & & \multicolumn{2}{|c|}{ Milligrams per liter } & \multicolumn{2}{|c|}{ Percent saturation } & & \\
\hline & Max & Min & Max & Min & Max & $\operatorname{Min}$ & $\operatorname{Max}$ & Min \\
\hline $\begin{array}{l}1 \\
2 \\
3 \\
4 \\
5\end{array}$ & $\begin{array}{l}18 \\
18 \\
20 \\
21 \\
22\end{array}$ & $\begin{array}{l}16 \\
15 \\
16 \\
18 \\
20\end{array}$ & $\begin{array}{l}9.4 \\
9.3 \\
9.2 \\
8.8 \\
8.3\end{array}$ & $\begin{array}{l}8.7 \\
8.8 \\
8.6 \\
7.9 \\
7.4\end{array}$ & $\begin{array}{l}99 \\
93 \\
94 \\
94 \\
94\end{array}$ & $\begin{array}{l}87 \\
87 \\
92 \\
83 \\
81\end{array}$ & $\begin{array}{l}140 \\
145 \\
153 \\
170 \\
167\end{array}$ & $\begin{array}{l}120 \\
130 \\
130 \\
140 \\
150\end{array}$ \\
\hline $\begin{array}{r}6 \\
7 \\
8 \\
9 \\
10\end{array}$ & $\begin{array}{l}24 \\
24 \\
25 \\
26 \\
26\end{array}$ & $\begin{array}{l}22 \\
23 \\
23 \\
24 \\
24\end{array}$ & $\begin{array}{l}8.2 \\
7.6 \\
6.9 \\
8.1 \\
8.0\end{array}$ & $\begin{array}{l}6.9 \\
5.7 \\
5.1 \\
5.7 \\
5.6\end{array}$ & $\begin{array}{l}96 \\
89 \\
82 \\
99 \\
96\end{array}$ & $\begin{array}{l}79 \\
66 \\
59 \\
68 \\
67\end{array}$ & $\begin{array}{l}157 \\
185 \\
207 \\
220 \\
220\end{array}$ & $\begin{array}{l}\mathbf{1 4 7} \\
157 \\
\mathbf{1 8 7} \\
200 \\
210\end{array}$ \\
\hline $\begin{array}{l}11 \\
12 \\
13 \\
14 \\
15\end{array}$ & $\begin{array}{l}26 \\
26 \\
26 \\
27 \\
26\end{array}$ & $\begin{array}{l}23 \\
23 \\
23 \\
23 \\
24\end{array}$ & $\begin{array}{l}9.3 \\
9.9 \\
8.9 \\
7.7 \\
6.1\end{array}$ & $\begin{array}{l}6.3 \\
6.6 \\
6.6 \\
4.7 \\
3.5\end{array}$ & $\begin{array}{r}112 \\
119 \\
106 \\
90 \\
73\end{array}$ & $\begin{array}{l}73 \\
76 \\
76 \\
57 \\
\mathbf{4 1}\end{array}$ & $\begin{array}{l}217 \\
215 \\
207 \\
223 \\
232\end{array}$ & $\begin{array}{l}210 \\
200 \\
200 \\
200 \\
216\end{array}$ \\
\hline $\begin{array}{l}16 \\
17 \\
18 \\
19 \\
20\end{array}$ & $\begin{array}{l}27 \\
26 \\
24 \\
24 \\
26\end{array}$ & $\begin{array}{l}24 \\
23 \\
23 \\
23 \\
23\end{array}$ & $\begin{array}{l}5.0 \\
6.4 \\
6.2 \\
6.6 \\
6.9\end{array}$ & $\begin{array}{l}3.6 \\
3.6 \\
4.3 \\
4.2 \\
4.5\end{array}$ & $\begin{array}{l}60 \\
75 \\
73 \\
78 \\
83\end{array}$ & $\begin{array}{l}42 \\
43 \\
49 \\
49 \\
52\end{array}$ & $\begin{array}{l}232 \\
240 \\
244 \\
244 \\
230\end{array}$ & $\begin{array}{l}222 \\
228 \\
234 \\
231 \\
212\end{array}$ \\
\hline $\begin{array}{l}21 \\
22 \\
23 \\
24 \\
25\end{array}$ & $\begin{array}{l}25 \\
23 \\
23 \\
23 \\
24\end{array}$ & $\begin{array}{l}23 \\
21 \\
21 \\
22 \\
22\end{array}$ & $\begin{array}{l}6.5 \\
7.3 \\
7.2 \\
6.8 \\
6.7\end{array}$ & $\begin{array}{l}4.2 \\
6.3 \\
6.6 \\
6.3 \\
6.0\end{array}$ & $\begin{array}{l}77 \\
84 \\
83 \\
79 \\
79\end{array}$ & $\begin{array}{l}49 \\
72 \\
75 \\
72 \\
69\end{array}$ & $\begin{array}{l}232 \\
110 \\
100 \\
100 \\
100\end{array}$ & $\begin{array}{r}110 \\
89 \\
90 \\
92 \\
91\end{array}$ \\
\hline $\begin{array}{l}26 \\
27 \\
28 \\
29 \\
30\end{array}$ & $\begin{array}{l}24 \\
26 \\
28 \\
29 \\
30\end{array}$ & $\begin{array}{l}23 \\
23 \\
26 \\
27 \\
27\end{array}$ & $\begin{array}{l}6.5 \\
6.2 \\
5.5 \\
4.5 \\
4.7\end{array}$ & $\begin{array}{l}5.9 \\
5.5 \\
4.2 \\
3.2 \\
2.6\end{array}$ & $\begin{array}{l}77 \\
75 \\
69 \\
58 \\
62\end{array}$ & $\begin{array}{l}69 \\
64 \\
51 \\
40 \\
33\end{array}$ & $\begin{array}{r}98 \\
128 \\
152 \\
238 \\
253\end{array}$ & $\begin{array}{r}88 \\
100 \\
126 \\
152 \\
228\end{array}$ \\
\hline
\end{tabular}

WATER QUALITY OF STREAMS

In the present report the descriptions of stream quality at selected places in the Lehigh River drainage system are presented in downstream sequence. The chemical character, dissolved-solids concentration, and hardness of Lehigh River water change in varying degrees throughout the river length (fig. 2).

\section{CHEMICAL QUALITY OF HEADWATER STREAMS DRAINING THE APPALACHIAN PLATEAUS}

Streams draining the Appalachian Plateaus are of similar chemical character. The predominant ions in the water are calcium and sulfate. Dissolved solids range from 14 to $40 \mathrm{mg} / \mathrm{l}$; the lower concentrations occur near the sources of tributaries. The waters are soft; they rarely exceed $25 \mathrm{mg} / \mathrm{l}$ of calcium and magnesium hardness. Calcium and magnesium, as milliequivalents per liter, constitute about 35-45 percent of the ions; sodium and potassium constitute about 5-15 percent. Low concentrations, less than $1 \mathrm{mg} / 1$, of iron and manganese are also found in these streams. Sulfate ions approximate $20-30$ percent, bicarbonate 10-20 percent, and chloride and nitrate, 10-15 percent of the total; fluoride occurs in trace amounts. Silica rarely exceeds $5 \mathrm{mg} / \mathrm{l}$. 
The $\mathrm{pH}$ of streams draining the Appalachian Plateaus ranges from 5.0 to 7.0. Acidity in these streams is usually due to carbonic acid and other organic acids that are products of decaying plant matter in swamps. The relatively high color of water in some streams also reflects the influence of decomposed vegetation.

\section{LEHIGH RIVER AT STODDARTSVILLE}

At Stoddartsville, in Luzerne County, the Lehigh River drains 91.7 square miles. The average discharge for 23 years (1944-66) was $178 \mathrm{cfs}$, or about $115 \mathrm{mgd}$ (million gallons per day). The broken, mountainous country and general topography of the basin headwaters cause rapid overland flow during storms. The maximum discharge of $31,900 \mathrm{cfs}$ occurred during the tropical storms of August 1955; a minimum flow of $7.0 \mathrm{cfs}$ was observed September 26-27, 1964. Between 30 and 40 percent of the time the daily flow equaled or exceeded the average flow (Busch and Shaw, 1966).

The predominant ions, expressed as milliequivalents per liter, in water at Stoddartsville were calcium and sulfate-except at low flow, when the bicarbonate concentration exceeded that of sulfate. The water is soft and of excellent quality (table 6, p. H30) and supports several varieties of game fish, including brown and rainbow trout.

\section{TOBYHANNA AND TUNKHANNOCK CRERKS}

Tobyhanna Creek flows into the Francis E. Walter Reservoir near Stoddartsville. It drains 139 square miles of northwestern Monroe and northeastern Carbon Counties. Between October $19: 1$ and September 1966 the average discharge was $170 \mathrm{cfs}$, or $110 \mathrm{mgd}$. The maximum discharge of Tobyhanna Creek measured near B!akeslee was 2,250 cfs on March 27, 1963, and the minimum was 22 cfs Soptember 24-25, 1964. However, during the flood of August 19, 1c55, the discharge was estimated at 35,300 cfs. The water of Tobyhanna Creek is of a calcium bicarbonate type, low in solute concentrations, that contains traces of iron and manganese. Specific conductance ranged from 22 to 37 micromhos, and the $\mathrm{pH}$ ranged from 5.7 to 7.1. Brown and rainbow trout are in the creek.

The principal tributary to the Tobyhanna is Tunkhannock Creek, which drains 50 square miles of western Monroe and northeastern Carbon Counties, including a large swamp in Monroe County. The creek's mouth is 2 miles southeast of Blakeslee. The water of Tunkhannock Creek near Fernridge is of a mixed calcium sulfate bicarbonate type having low concentrations of solutes. The estimated average annual minimum discharge at Fernidge for 7 consecutive days during a recurrence interval of 10 years was $5.6 \mathrm{cfs}$, or $3.6 \mathrm{mgd}$ (Busch and Shaw, 1966).

BEAR CREEK

Bear Creek merges with the Lehigh River in the Francis E. Walter Reservoir. The creek is 13 miles long and drains 55.8 squar? miles, 
most of which is in Luzerne County. The water has a low solute concentration and is a calcium sulfate type. The estimated average annual minimum discharge of Bear Creek near White Haven, above the Walter dam, for 7 consecutive days during a recurrence interval of 10 years was $1.8 \mathrm{cfs}$, or $1.1 \mathrm{mgd}$.

\section{LEHIGH RIVER AT WHITE HAVEN AND LEHIGH TANNERY}

Near White Haven, about 6 river miles downstresm from the Francis E. Walter Reservoir dam, the Lehigh River $\mathrm{k}$ ad a specific conductance of 40 micromhos, a pH of 6.5, and a color of 30 units on June 16, 1966. At White Haven, river water is a mixed celcium sulfate bicarbonate type. The average discharge at White Haven was 520 cfs, or $336 \mathrm{mgd}$, for 9 years (1958-66).

Since 1944, intermittent sampling and analysis of the river at Lehigh Tannery, about 2 river miles downstream from White Haven, showed negligible changes in type between these places, and regardless of discharge, river water quality has been excellent. At Lehigh Tannery, the average discharge for 45 years was $667 \mathrm{cfs}$. or $431 \mathrm{mgd}$. Daily flow equaled or exceeded the average flow about 35 percent of the time.

\section{DILLDOWN CREEK}

Dilldown Creek is a tributary of Mud Run, which is $\varepsilon$ tributary to the Lehigh River in Carbon County. Mud Run drains 36 square miles of Monroe and Carbon Counties. Dilldown Creek is a low solute, calcium sulfate stream and is slightly acidic; the relatively high color of the stream water probably stems from swamp water. The average discharge of the creek near Long Pond is $5.15 \mathrm{cfs}$, or $3.3 \mathrm{mgd}$. About 35 percent of the time the daily flow equaled or exceeded the average flow. Game fish are plentiful in most parts of Dilldown Creek.

\section{CHEMICAL QUALITY OF STREAMS DRAINING THE TALLEY AND RIDGE PROVINCE}

The chemical character of streams draining the Valley and Ridge province ranges widely because of the influence of variable geology. The water in streams draining the region of coal deposits is acidic and very hard and contains high concentrations of calcium, sulfate, aluminum, iron, manganese, and free sulfuric acid. The streams draining limestone and dolomite are alkaline and hard and contain high concentrations of calcium, magnesium, and bicarbonate ions. Other streams draining shales, conglomerates, and sandstones have low concentrations of solutes.

\section{ACID-BEARING STREAMS}

The quality of the Lehigh River water changes signif cantly below Lehigh Tannery after the river receives the dischage of tributaries flowing in from the west. In this area of the basin, Sandy and Indian Runs and Pond, Quakake, Black, and Nesquehoning: Creeks, all 
affected by drainage from coal mines, show a sulfate content ranging from 44 to $583 \mathrm{mg} / \mathrm{l}$. Calcium and magnesium hardness, as calcium carbonate, ranges from 29 to $362 \mathrm{mg} / \mathrm{l}$ (table 6 , p. H32-33). The metal ions and hydrogen ions in mine waste also contribute to the water hardness. Calcium and magnesium comprise 65-75 percent of the cations, sodium and potassium 5-15 percent, aluminum about 20 percent, and iron and manganese about 3 percent. Sulfate comprises about $85-95$ percent of the anions; chloride, fluoride and nitrate occur in minor percentages; and there is little or no bicarbonate. Aluminum concentrations were as much as $16 \mathrm{mg} / \mathrm{l}$, iron $2 \mathrm{mg} / \mathrm{l}$, silica $14 \mathrm{mg} / \mathrm{l}$, and manganese approximately $5 \mathrm{mg} / \mathrm{l}$ in acidic streams at locations several miles downstream from inflowing mine drainage.

\section{ALKALINE-TYPE STREAMS}

In the central part of the Lehigh River drainage basin the tributaries-Mahoning, Pohopoco, Lizard, and Aquashicola Creeks-drain a region underalin by shale, sandstone, conglomerate, and some limestone. Except for Aquashicola Creek at Palmerton, these streams contain a calcium bicarbonate type water which is low in dissolved solids.

Aquashicola Creek has a calcium sodium sulfate type of water containing relatively high concentrations of dissolved solids. Punoff leaches material from the area drained by this stream and accounts for most of the dissolved solids in the water at Palmerton. Zinc-recovery works in the basin also contribute to the dissolved solids in this stream. A sample of water at Palmerton on September 18, 1964, contained 275 $\mathrm{mg} / \mathrm{l}$ dissolved solids (specific conductance 449 micromhos) and a calcium magnesium hardness of $146 \mathrm{mg} / \mathrm{l}$.

\section{LEHIGH RIVER AT WALNUTPORT}

Walnutport is about 40 river miles down river from the Francis $\mathrm{E}$. Walter dam, approximately halfway between the source and mouth of the Lehigh River. The river drains 889 square miles at Walnutport, where during 20 years (1947-66) the average discharge was 1,739 cfs, or 1,123 mgd. For the period 1947-60 the daily flow equaled or exceeded the average flow $30-40$ percent of the time.

In this part of the river can be observed the effectiveness of neutralization and dilution by some tributaries to lessen the deleterious influence of acid-bearing streams on water quality. River water here is a calcium sulfate type and is commonly of good quality for most uses. The concentrations of solutes in river water at Walnutport are at their highest during the summer months and early autumn, during low flow. Only moderate treatment of river water is required for its us? as a public or industrial supply.

Intermittent chemical analyses of the river at Walnutport fron 1950 to 1966 showed that dissolved-solids concentrations ranged from 41 to 
$131 \mathrm{mg} / \mathrm{l}$ and that $\mathrm{pH}$ ranged from 4.6 to 7.0. Calcium s.nd magnesium hardness ranged from 20 to $86 \mathrm{mg} / \mathrm{l}$. Maximum har tness occurred September 18, 1964, when most eastern Pennsylvanis. streams were affected by drought. Minimum hardness of $20 \mathrm{mg} / \mathrm{l}$ occurred June 20, 1966, when controlled releases of impounded water wene made to the river from the Francis E. Walter Reservior. Normally this section of the river is nearly saturated with dissolved oxygen.

\section{OTHER STREAMS IN THE VALLEY AND RIDGE PROVINC"}

Streams in the southern part of the Valley and Ridge province, notably Little Lehigh, Monocacy, Coplay, Cedar, and Jordan Creeks, are underlain by extensive beds of Cambrian and Ordovician limestone and dolomite. Such rocks greatly influence the chemical quality of the streams that cross them. The limestones are dense, hard, brittle, and soluble. Subsurface channels are dissolved out along fractures by percolating water charged with carbon dioxide. Water that seeps from these rocks into streams contains high concentrations of calcium, magnesium, and bicarbonate. Consequently, water in streams of this area is a calcium bicarbonate type and alkaline. The dissolved-solids concentrations range from 100 to $400 \mathrm{mg} / 1 ; \mathrm{pH}$ ranges from about 7.0 to 8.5. Commonly, calcium and magnesium hardness exceeds $100 \mathrm{mg} / \mathrm{l}$ and may often exceed $200 \mathrm{mg} / \mathrm{l}$ during periods of low streamflow.

Calcium and magnesium constitute 80-95 percent of the cations, and sodium and potassium about 5-20 percent. Iron and manganese are present in minor percentages, but, combined, they rarely exceed $1.0 \mathrm{mg} / \mathrm{l}$. Silica content is usually less than $10 \mathrm{mg} / \mathrm{l}$. Bicarbonate constitutes about 60-80 percent of the anions, sulfate 10-35 percent, and chloride and nitrate 5-10 percent. Fluoride is present in trace amounts.

The average discharge of Little Lehigh Creek near Allentown for 21 years (1946-66) was $88.3 \mathrm{cfs}$, or $57 \mathrm{mgd}$; that for Monocacy Creek at Bethlehem for 18 years (1949-66) was $45.5 \mathrm{cfs}$, or $29.3 \mathrm{mgd}$; and that for Jordan Creek at Allentown for 22 years (1945-66) was $106 \mathrm{cfs}$, or $68.5 \mathrm{mgd}$. The daily flow in Little Lehigh Creek equaled or exceeded its average flow 40-50 percent of the time, and daily flow in the other two creeks equaled or exceeded average flow 30.40 percent of the time.

\section{LEHIGH RIVER AT CATASAUQUA}

Lehigh River water at Catasauqua was frequently examined for quality variations from October 1, 1944, through September 30, 1953. During this time more than 2,800 daily samples were taken and composited into sets of 10 samples each. A complete chemical analysis was made of each composited set.

Catasauqua is about 9 river miles upstream from Pethlehem and is above the confluence of Jordan, Little Lehigh, end Monocacy Creeks. River water at Catasauqua is a calcium sulfate type, and 
most of the time its quality is good for most purposes after moderate treatment. For the period of record, dissolved solids ranged from 45 to $393 \mathrm{mg} / \mathrm{l}, \mathrm{pH}$ ranged from 5.3 to 7.6 , and calcium and magr osium hardness ranged from 24 to $258 \mathrm{mg} / 1$ (table 2).

The median specific conductance for the same period we.s 119 micromhos. The cumulative frequency of specific conductance at Catasauqua and the concentration levels for some chemical constituents from 1945 to 1952 are presented in table 3.

The concentration of dissolved solids and the calcium and magr osium hardness of Lehigh River water at Catasauqua are, respectively, about 66 and 42 percent of specific conductance (fig. 5).

\section{CHEMICAL QUALITY OF STREAMS DRAINING THE NEW ENC LAND PROVINCE}

Below Bethlehem the Lehigh River and its tributaries drain the New England province. Stream valleys are underlain by limestone and dolomite, and the high country is mainly Precambrian crystalline rock (Hall, 1934).

\section{SAUCON CREEK}

Saucon Creek is 16.5 miles long, and, although its drainage area is relatively small $(58.2 \mathrm{sq} \mathrm{mi})$, the limestone terrane that it drains imparts alkaline characteristics to the stream which can neutralize acidic water where the two mix. At Friedensville, 0.3 mile downstream

TABLE 2.-Maximum and minimum values of physical and chemical properties, Lehigh River at Catasauqua, 1944-53

[Results in milligrams per liter except as indicated]

\begin{tabular}{|c|c|c|c|}
\hline Property & & $\operatorname{Max}$ & Min \\
\hline 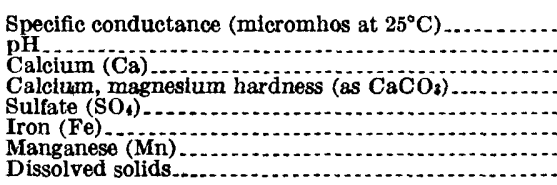 & (2) & $\begin{array}{l}564 \\
7.6 \\
59 \\
258 \\
221 \\
1.24 \\
393\end{array}$ & $\begin{array}{r}70 \\
5.3 \\
6 \\
24 \\
21 \\
0 \\
0 \\
45\end{array}$ \\
\hline
\end{tabular}

1 Exceeds U.S. Public Health Service drinking water standards.

TABLE 3.-Given values of physical and chemical properties that were equaled or exceeded for indicated percent of days, Lehigh River at Catasauqua, 1945-52

[Results in milligrams per liter except as indicated]

\begin{tabular}{|c|c|c|c|c|c|}
\hline \multirow{2}{*}{ Property } & \multicolumn{5}{|c|}{ Percent of days } \\
\hline & 10 & 25 & 50 & 75 & 90 \\
\hline 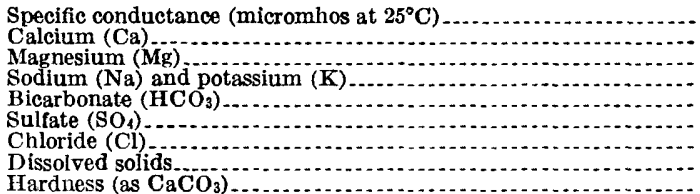 & $\begin{array}{l}200 \\
19 \\
6.6 \\
7.4 \\
22 \\
60 \\
4.0 \\
127 \\
74\end{array}$ & $\begin{array}{c}162 \\
15 \\
5.4 \\
5.9 \\
17 \\
48 \\
3.3 \\
104 \\
60\end{array}$ & $\begin{array}{l}130 \\
12 \\
4.3 \\
4.7 \\
13 \\
38 \\
2.7 \\
84 \\
47\end{array}$ & $\begin{array}{l}107 \\
9.8 \\
3.6 \\
3.8 \\
9 \\
32 \\
23 \\
70 \\
39\end{array}$ & $\begin{array}{l}92 \\
8.3 \\
3.0 \\
3.2 \\
7 \\
27 \\
2.1 \\
60 \\
33\end{array}$ \\
\hline
\end{tabular}




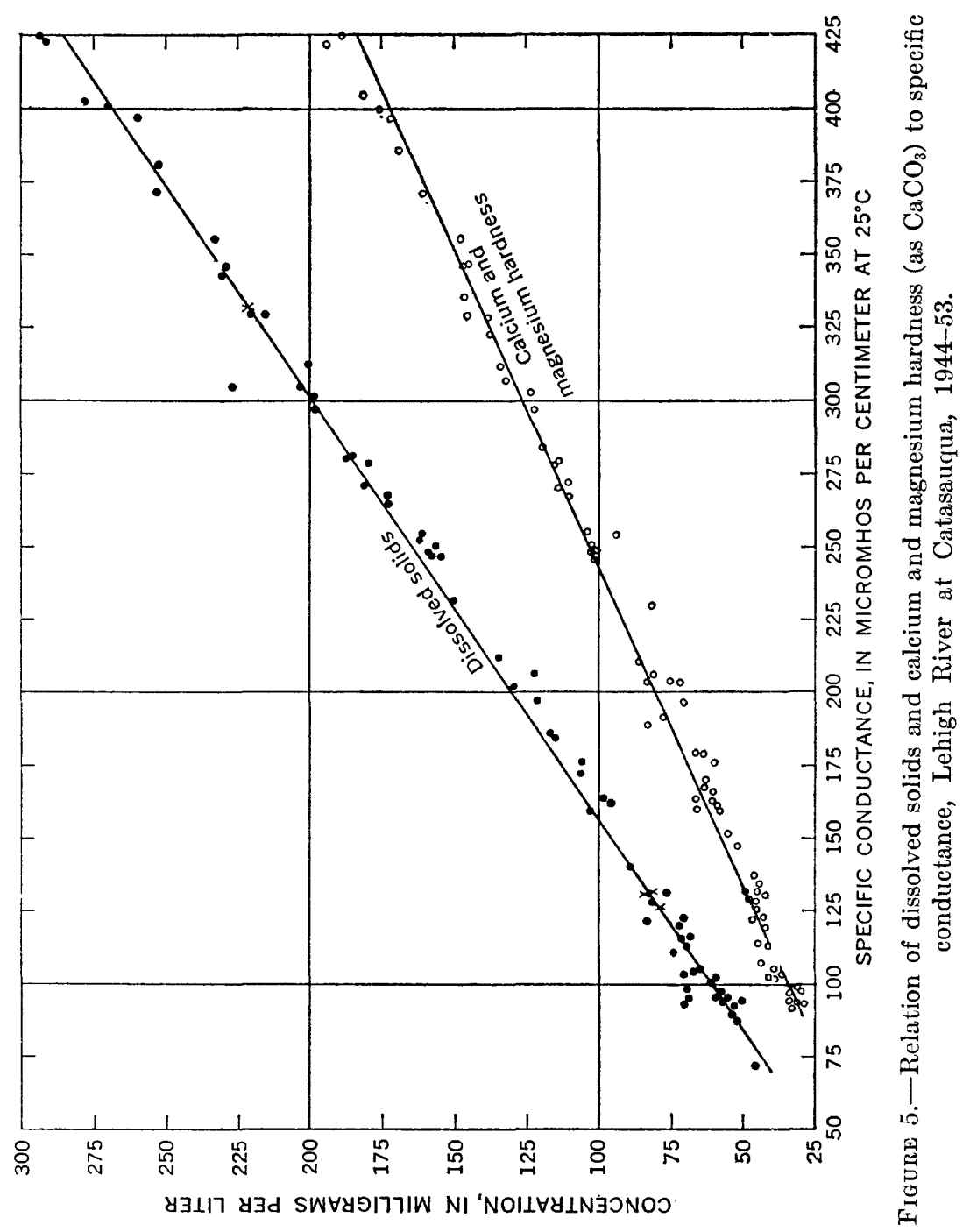


from South Branch Saucon Creek, the average discharge for 5 years (1949-53) was $42.7 \mathrm{cfs}$, or about $28 \mathrm{mgd}$. The maximum discharge, $1,330 \mathrm{cfs}$, occurred November 25, 1950; the minimum, $6.4 \mathrm{cfs}$, occurred September 26, 1950. Water pumped from a zinc mine near Friedensville flows into this stream. From 1949 to 1953 dail flow in Saucon Creek exceeded the average flow 30-40 percent of the time (Busch and Shaw, 1966).

\section{LEHIGH RIVER AT BETHLEHEM AND GLENDON}

At Bethlehem, about 12 river miles upstream from the mouth of the Lehigh, the river drains 1,279 square miles, including the area drained by Monocacy Creek. The average discharge of the Lehigh at Bethlehem for 60 years $(1902-04,1909-66)$ was $2,236 \mathrm{cfs}$, or 1,445 mgd. The maximum discharge, 92,000 efs, occurred May ¿3, 1942; the minimum, $125 \mathrm{cfs}$, occurred June 28, 1965.

Lehigh River water at Bethlehem is a mixed calcium bicnrbonate sulfate type. During an average or below-average flow, solutes are more concentrated than when the flow is above average, and bicarbonate usually predominates in the stream water; when discharge is above average, sulfate usually predominates. The relationship of dissolved solids and specific conductance in Lehigh River water at Bethlehem (1959-66) is shown in figure 6.

About 8.5 miles downstream from Bethlehem, at Glendon, the drainage area is 71 square miles larger than at Bethlehem. A comparison of chemical analyses at these locations shows a change of less than 5 percent in specific conductance, calcium and magnesium hardness, and bicarbonate, and sulfate content. During the 1957 and 1؟ 58 water years, the specific conductance of river water at Glendon did not exceed 200 micromhos for 50 percent of the time (fig. 7). Orcasional fish kills in this part of the river are probably caused by industrial waste discharges, which reduce the concentration of oxygen in the water. (U.S. Department of Health, Education, and Welfare, 1964).

\section{LEHIGH RIVER AT EASTON}

At Easton the Lehigh River drains 1,364 square miles. The average discharge of the Lehigh at Easton for $\mathbf{5 8}$ years of record was approximately 2,320 cfs, or 1,499 mgd.

The water at Easton is a mixed calcium sulfate bicarbonate type. These ions make up about 65-75 percent of the dissolved solids. From October 1961 through March 1967, dissolved solids in river water ranged from 75 to $243 \mathrm{mg} / \mathrm{l}$. The varying concentrations had $\varepsilon . n$ inverse relationship to stream discharge. The hardness, caused principally by calcium and magnesium, ranged from 35 to $150 \mathrm{mg} / 1 ; \mathrm{pH}$ ranged from 6.4 to 7.7. Specific conductance ranged from 82 micromhos $M$ arch 15 , 1964, to 581 micromhos August 19, 1963. However, 60 percent of the 


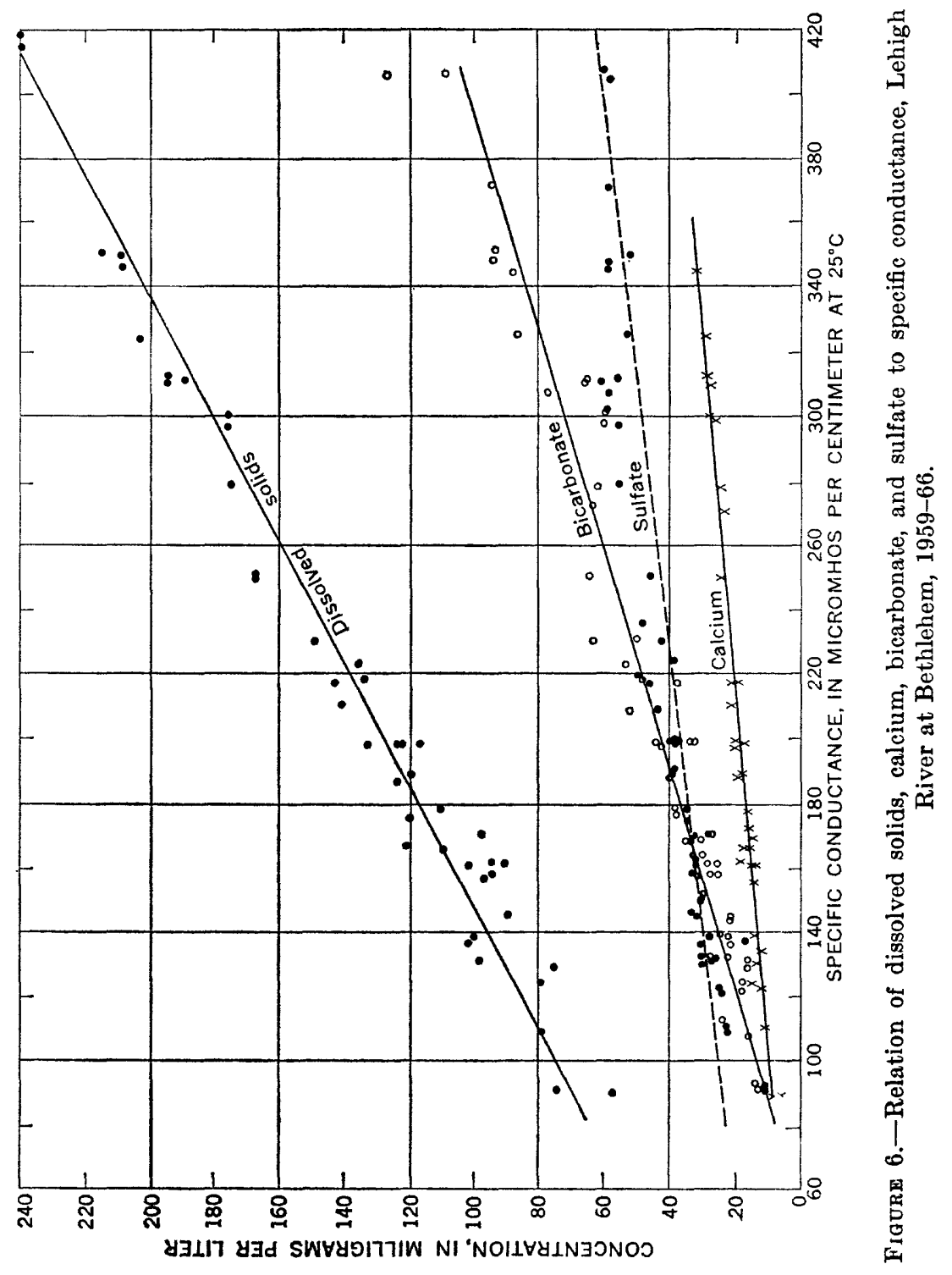


time specific conductance did not exceed 265 micromhos (fig. 8); during the 1966 water year the median was 174 micromhos. Daily specific conductances of the river at Easton during the 1966 water year are shown in table 4 . The monthly maximum, minimum, and mean values for dissolved oxygen, specific conductance, ard temperature of Lehigh River water at Easton are shown in table 5 . These quality parameters were recorded by instrument from May 1966 to April 1967.

The concentration of dissolved solids in river water can be estimated by the specific conductance. The relationship between dissolve $d$ solids $(\mathrm{ds})$ and specific conductance $(K)$ at Easton is illustrated in figure 9. The result of the plotting of these variables is:

$$
\mathrm{ds}=0.63 K+10
$$

The river water temperature at Easton from October 1962 to September 1965 was equal to or less than $22^{\circ} \mathrm{C} 75$ percent of the time (fig. 10). Seasonal variations, daily maximum and minimum averages, and monthly averages from October 1962 to September 1966 are shown in figure 11.

\section{SUMMARY}

Because of environmental factors such as climate, geolozy, and land and water use, the quality of water in the Lehigh River varies considerably from the river's source to its mouth.

The headwaters of the main river are fed by streams very low in solutes. Some of these streams in the Appalachian Plateaus contain drainage from swamps of glacial origin, which imparts a high color and acidity to water because of decaying matter. However, the near purity of most streams in the Lehigh headwaters is indicated by their low specific conductance (less than 50 micromhos). The lowest specific conductance of natural water in Pennsylvania ever recorded by the Geological Survey was 10 micromhos at Dilldown Creek, a tributary that flows through State game and forest lands in the scenic Pocono Mountains of Monroe and Carbon Counties. The headwaters of the Lehigh River; Dilldown, Choke, Bear, Tobyhanna, and Tunkhannock Creeks; and the main river provide habitat for an abundant population of brown and rainbow trout and other game fish.

In the middle part of the basin, the Lehigh receives the waters of several streams that transport acidic coal-mine wastes. Some mine water is also transported from abandoned mines in the Schuylkill River basin by way of the Nesquehoning drainage tunnel. Sandy, Pond, and Indian Runs and Black, Quakake, and Nesquehoning Creeks flow from the west to join the Lehigh, bringing mine drainage from the eastern Middle anthracite field. However, below the confluence of these streams with the Lehigh, alkaline water form Po. 


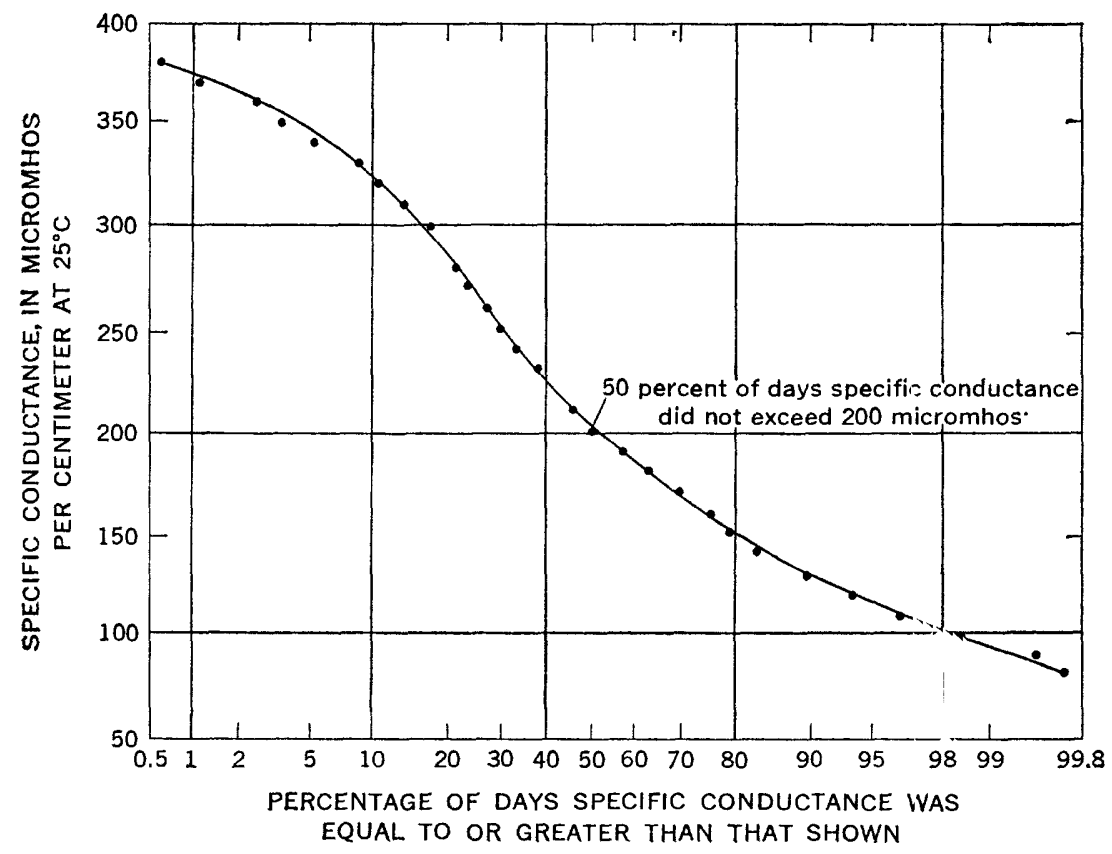

Figure 7.-Cumulative frequency curve of specific conductance, Lehigh River at Glendon, 1956-58.

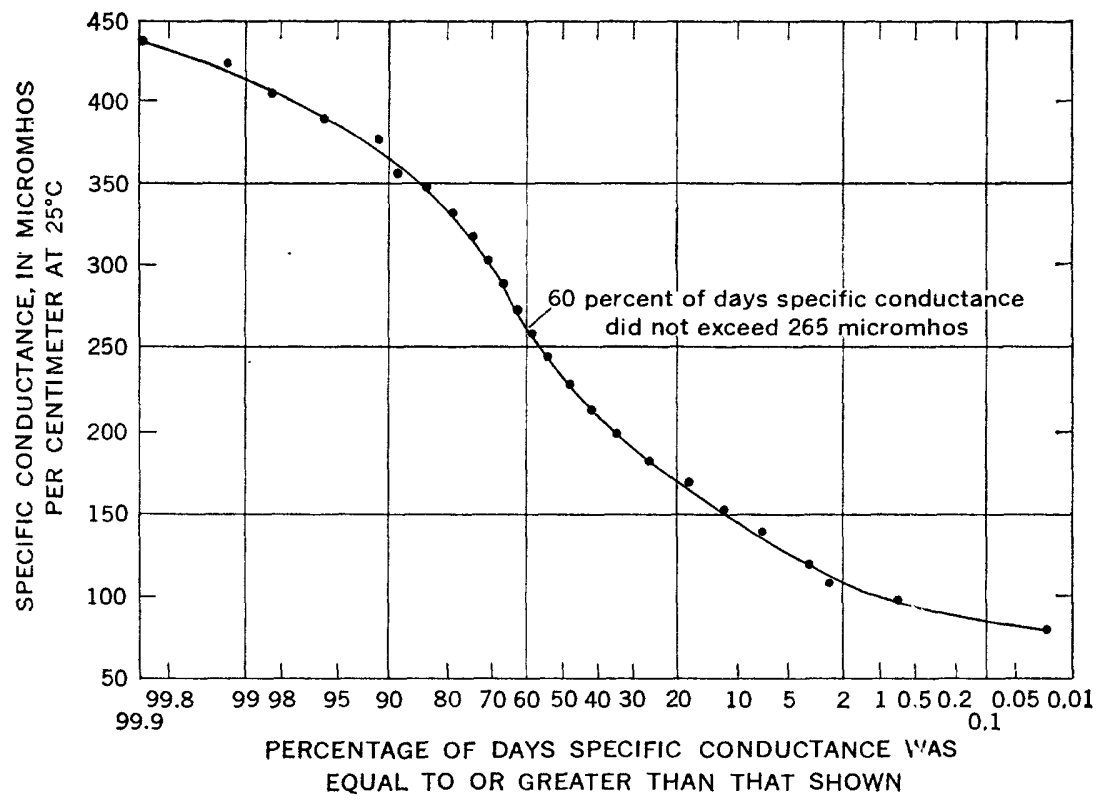

FIgURE 8.-Cumulative frequency curve of specific conductance, Lehigh River at Easton, October 1962 to September 1966. 


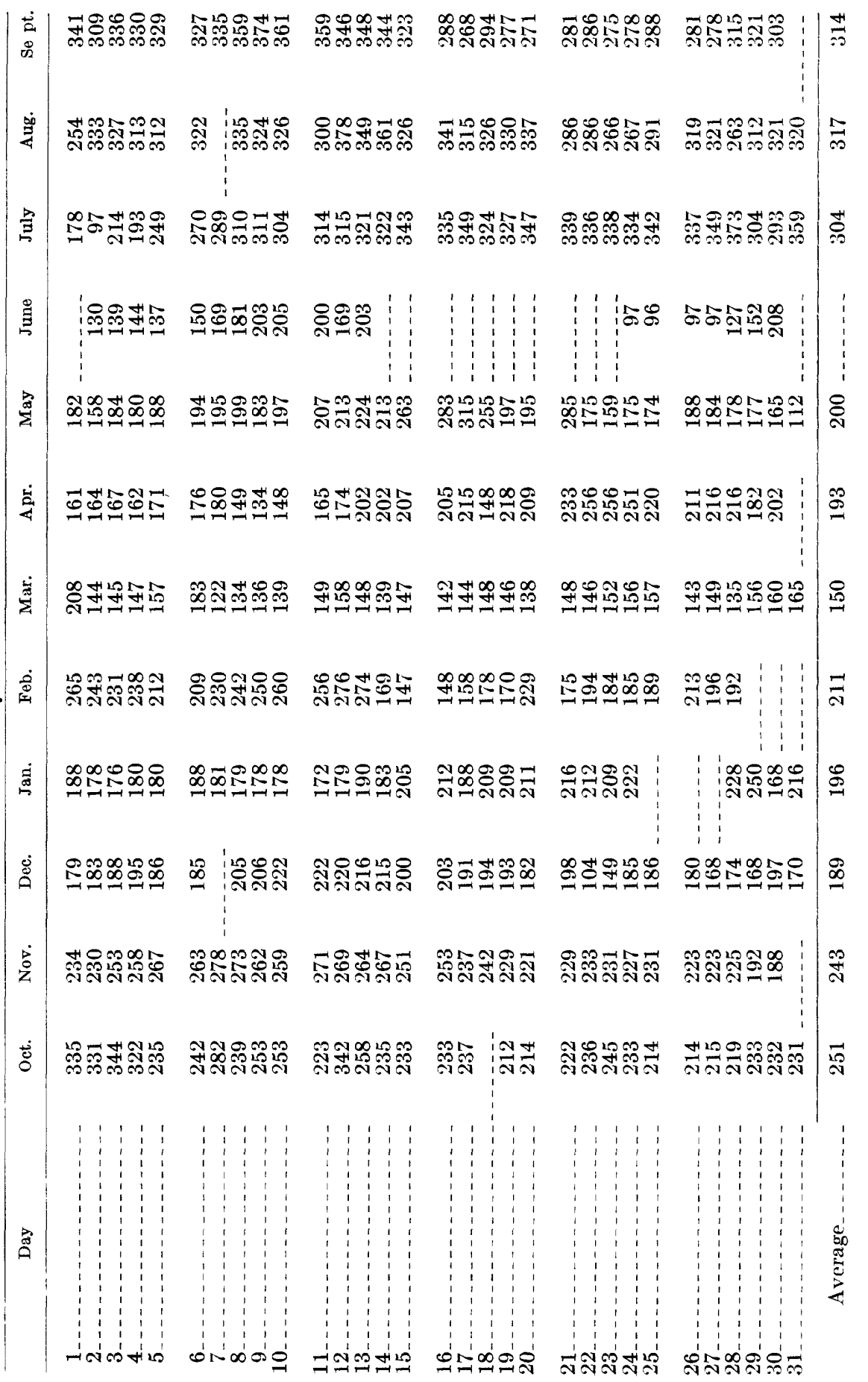


TABLE 5.-Continuous recording of water quality by instrument, Lehigh River at Easton, May 1966 to April 1967

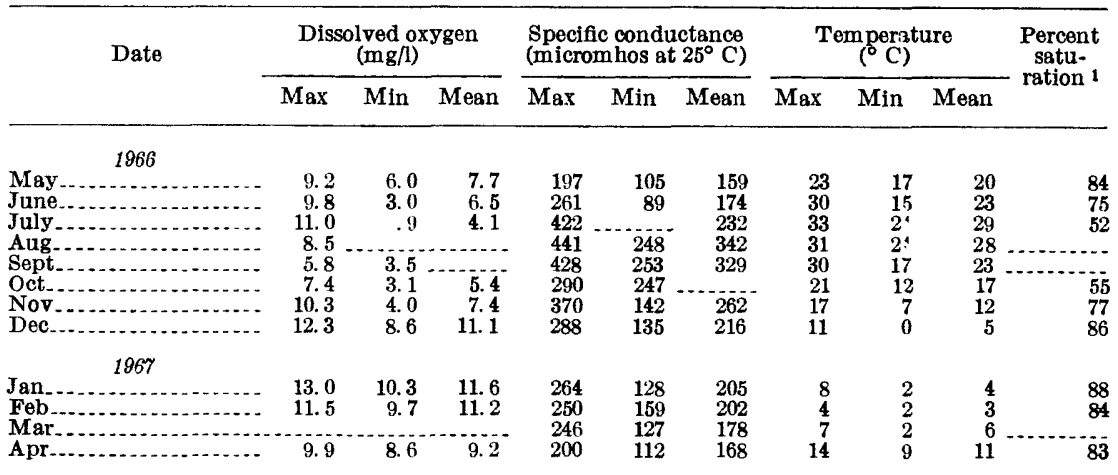

Derived from mean monthly dissolved oxygen and temperature records.

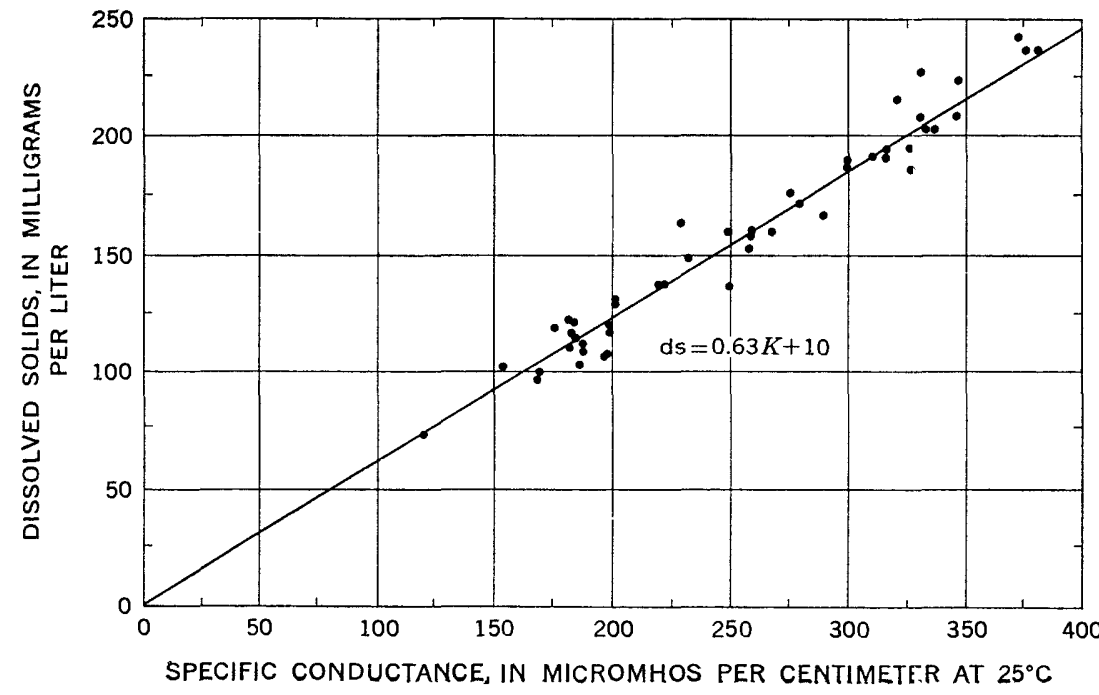

FIGURE 9.-Relationship between dissolved solids and specific conductance, Lehigh River at Easton, 1961-66. 
WATER, LEHIGH RIVER BASIN, PENNSYLVANIA

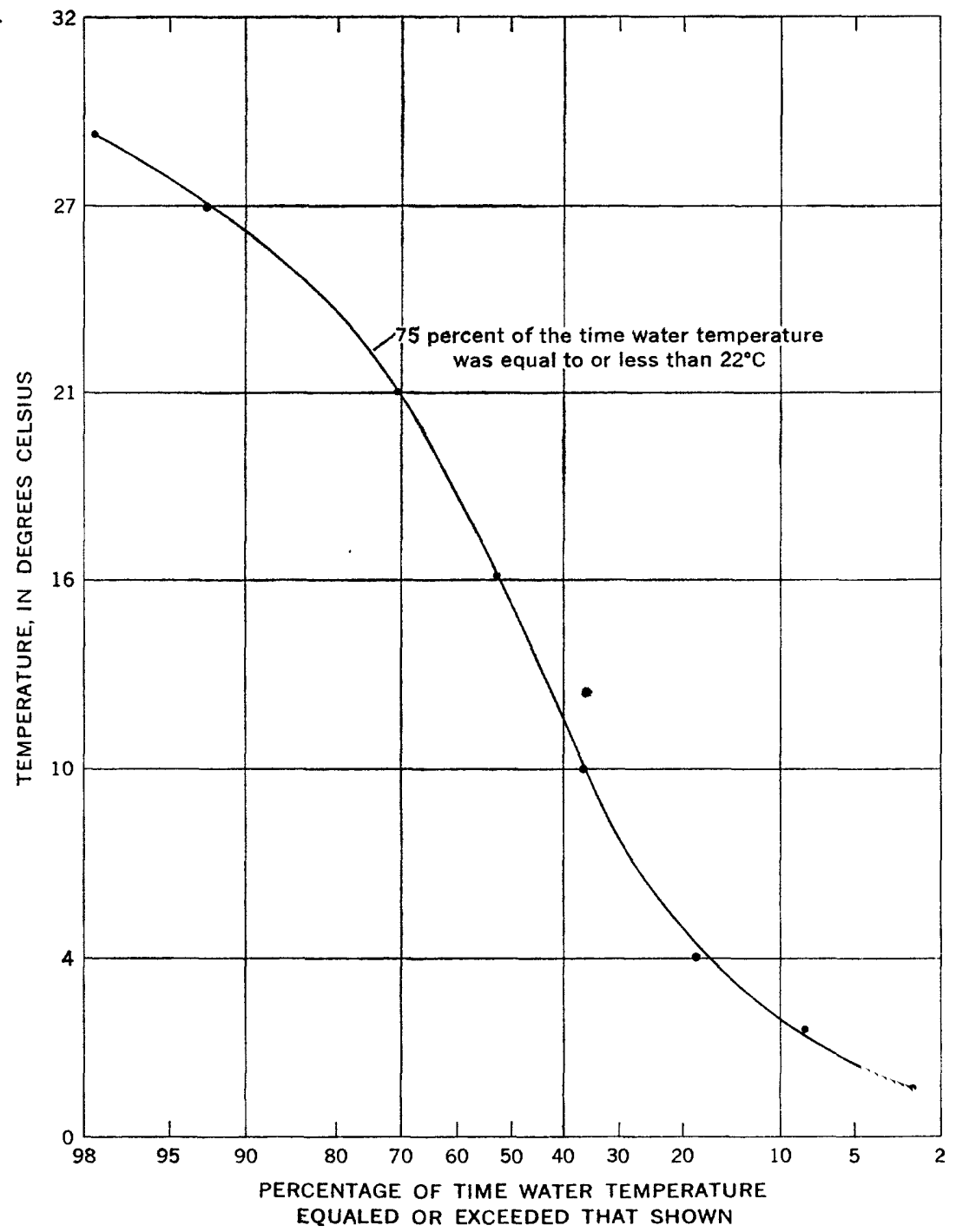

Figure 10.-Cumulative frequency curve of water temperature, Lehigh River at Easton, October 1962 to September 1965. 


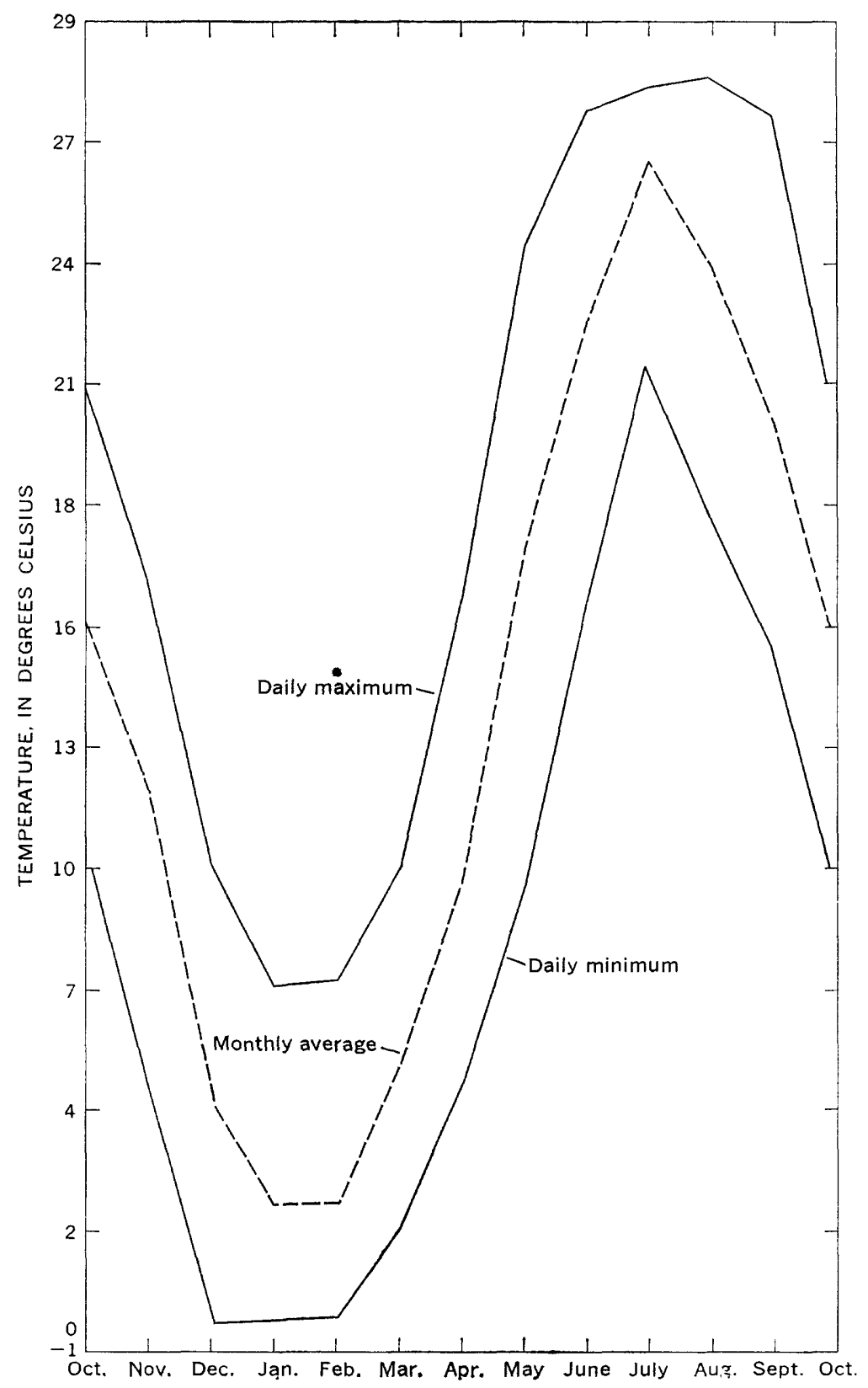

Figure 11.-Daily maximum and minimum, and monthly averages of, water temperature, Lehigh River at Easton, October 1962 to September 1966. 
hopoco, Wild, Lizard, Aquashicola, Buckwheat, and Hoker daqua Creeks dilutes and neutralizes the acidity so that the river is again approximately neutral and requires only a moderate amount of treatment for most uses.

Where the Lehigh flows into the Delaware at Easton, its water is a mixed type with calcium, sulfate, and bicarbonate ions predominating. Sixty percent of the time from 1962 to 1966 , the specific conductance did not exceed 265 micromhos; it ranged from 86 to 581 micromhos. The median specific conductance during the 1966 water year was 174 micromhos.

Water temperature at Easton from 1962 to 1965 was equal to or less than $22^{\circ} \mathrm{C} 75$ percent of the time. Water hardness, caused mostly by calcium and magnesium, ranged from 35 to $150 \mathrm{mg} / \mathrm{l}$.

There is a strong public consciousness for protecting the chemical and sanitary quality of the Lehigh River because of the river's economic importance as a water supply and because of its latent potential for esthetic enjoyment and recreational uses. This report shows that river water contains adequate oxygen most of the time for the oxidation of waste loads that may now be entering the stream. At times, however, the concentration of oxygen in the lower Lehigh is sufficiently low (less than $1.0 \mathrm{mg} / \mathrm{l}$ ) to cause concern. Oxygen deficits are caused by acid mine drainage and other industrial waste discharges. The effects are moderate to severe. The most recently reported fish kills in the Lehigh River have come from the lower basin areas between Allentown and Easton, where the Pennsylvania Fish Commission reports that channel catfish, smallmouth and largemouth bass, suckers. bullheads, eels, and fallish are in the river.

\section{REFERENCES}

Busch, W. F., and Shaw, L. C., 1960, Floods in Pennsylvania, frequercy and magnitude: U.S. Geol. Survey open-file rept., $231 \mathrm{p}$.

1966, Pennsylvania streamflow characteristics, low-flow frequency and flow duration: Pennsylvania Department of Forests and Waters Water Resources Bull. 1, 289 p.

California State Water Pollution Control Board, 1963, Water quality criteria: Pub. 3A, 512 p.

Hall, G. M., 1934, Ground water in southeastern Pennsylvania: Pennsylvania Geol. Survey, 4th ser., Bull. W2, 255 p.

Lohman, S. W., 1937, Ground water in northeastern Pennsylvania: Pennsylvania Geol. Survey, 4th ser., Bull. W4, $312 \mathrm{p}$.

McCarren, E. F., and Keighton, W. B., 1967, Effects of released reservoir water on quality of the Lehigh River, Pennsylvania, in Geological Survey Research 1967: U.S. Geol. Survey Prof. Paper 575-D, p. D262-D266.

Parker, G. G., Hely, A. G., Keighton, W. B., Olmsted, F. H., 1964, Water resources of the Delaware River basin: U.S. Geol. Survey Prof. Paper 381, $200 \mathrm{p}$.

Pennsylvania Fish Commission, 1969, Fisherman's Guide: 41 p.

U.S. Army Corps of Engineers, 1967, Water resources development by the U.S. Army Corps of Engineers in Pennsylvania: U.S. Army Engineer, North Atlantic Division, 102 p. 


\section{H28 CONTRIBUTIONS TO THE HYDROLOGY OF THE UITTED STATES}

U.S. Geological Survey, State Cooperative report 1968, Water resources data for Pennsylvania, Part 1, Surface water records, 1967: Basic data, prepared in cooperation with the Pennsylvania Dept. Forests and Weters and other agencies.

U.S. Department of Health, Education, and Welfare, 1964, Pollution-caused fish kills in 1964.

U.S. Weather Bureau, 1964, Climatic summary of the U.S., Supr'ement for 1951 through 1960, Pennsylvania, Decennial census of U.S. climate. 
TABLE 6 


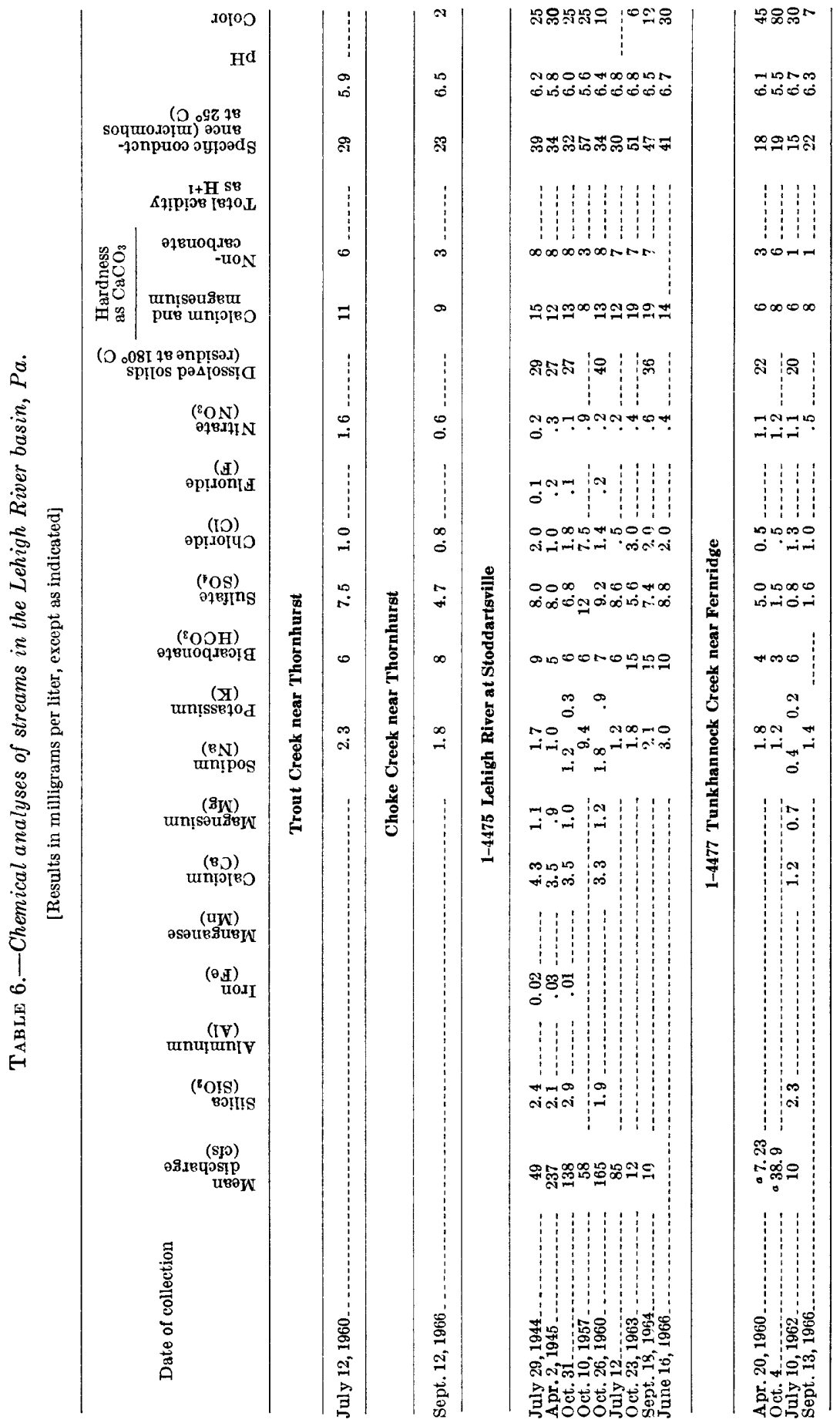


WATER, LEHIGH RIVER BASIN, PENNSYLVANIA

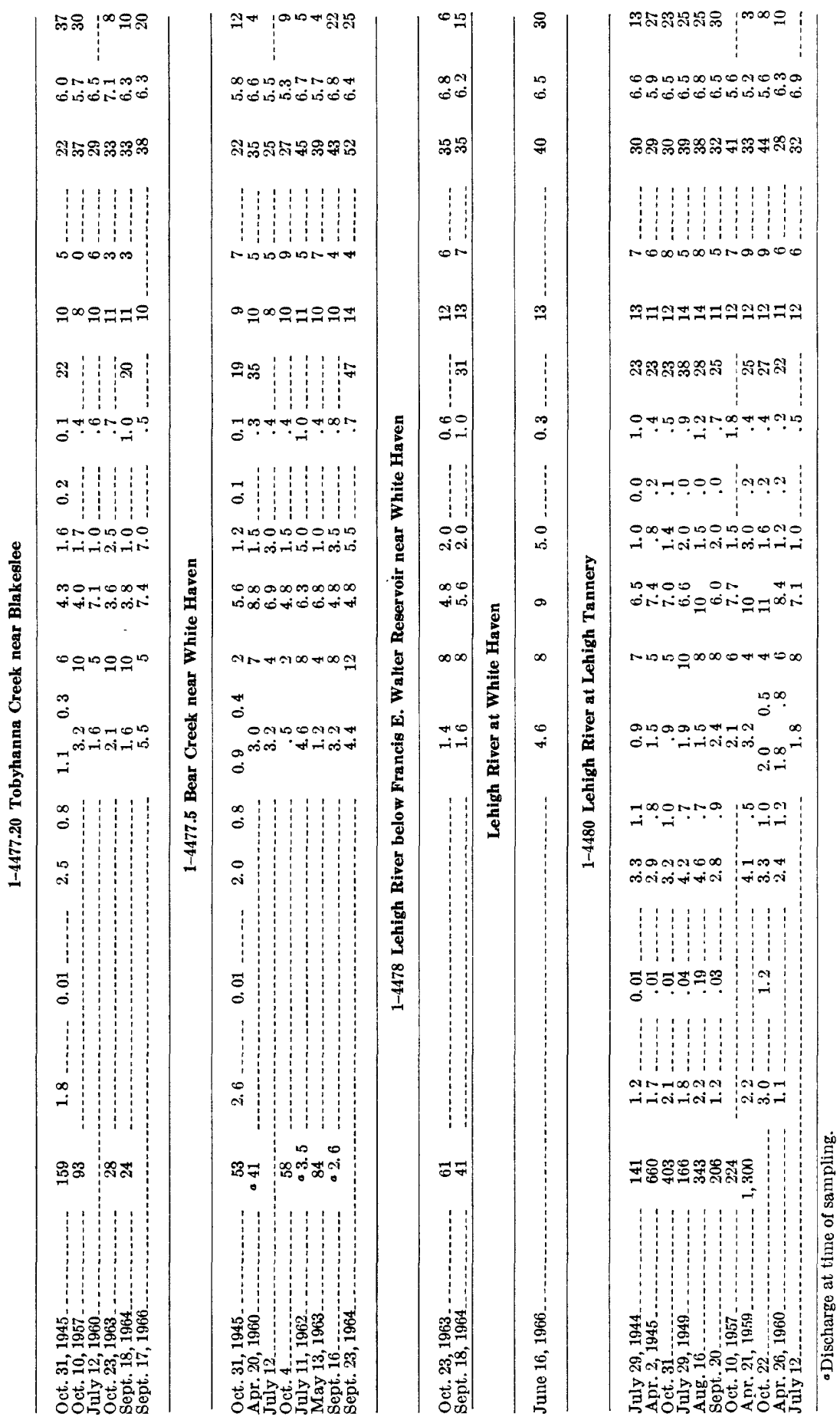




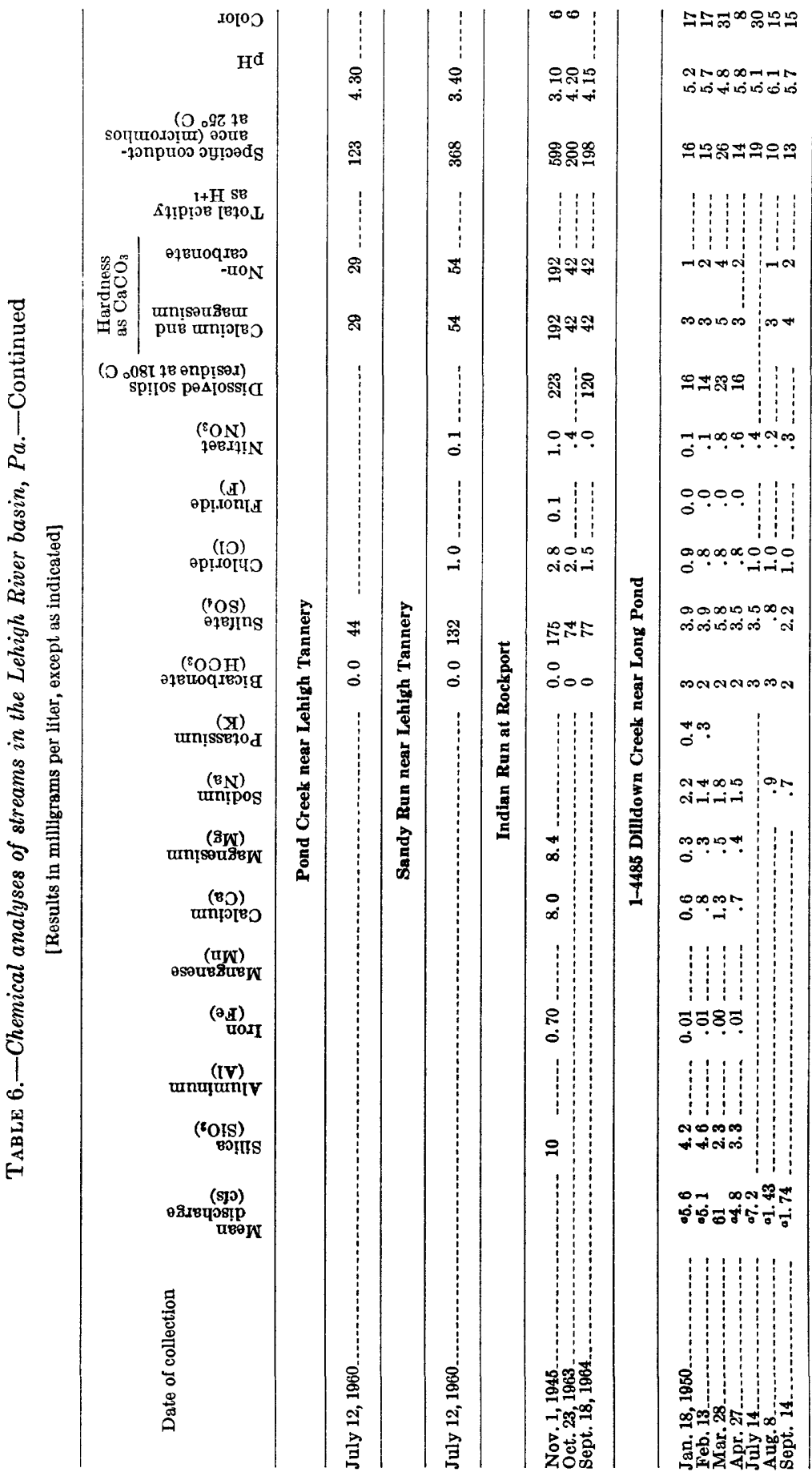


WATER, LEHIGH RIVER BASIN, PENNSYLVANIA

H33

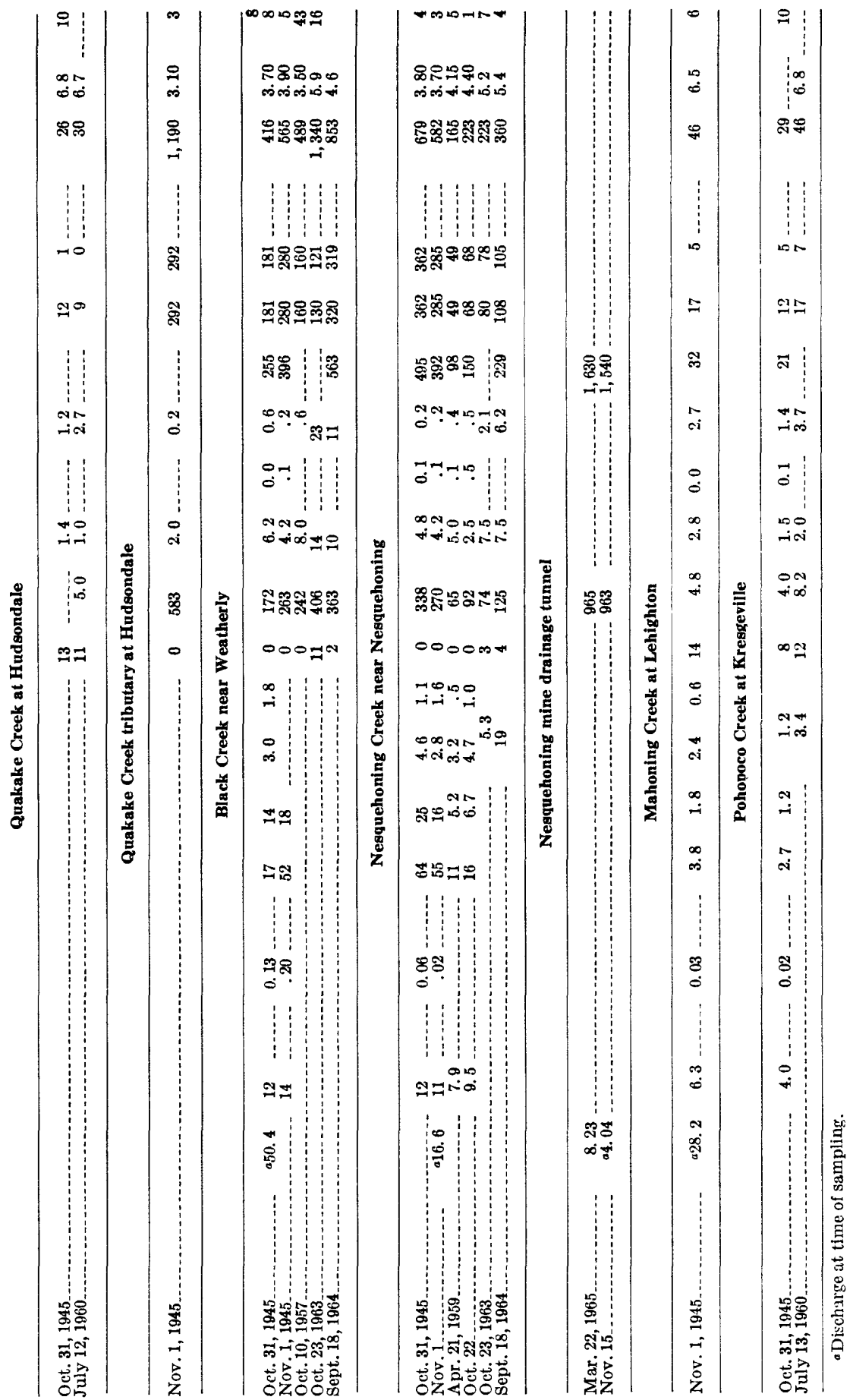


H34 CONTRIBUTIONS TO THE HYDROLOGY OF THE UNITED STATES

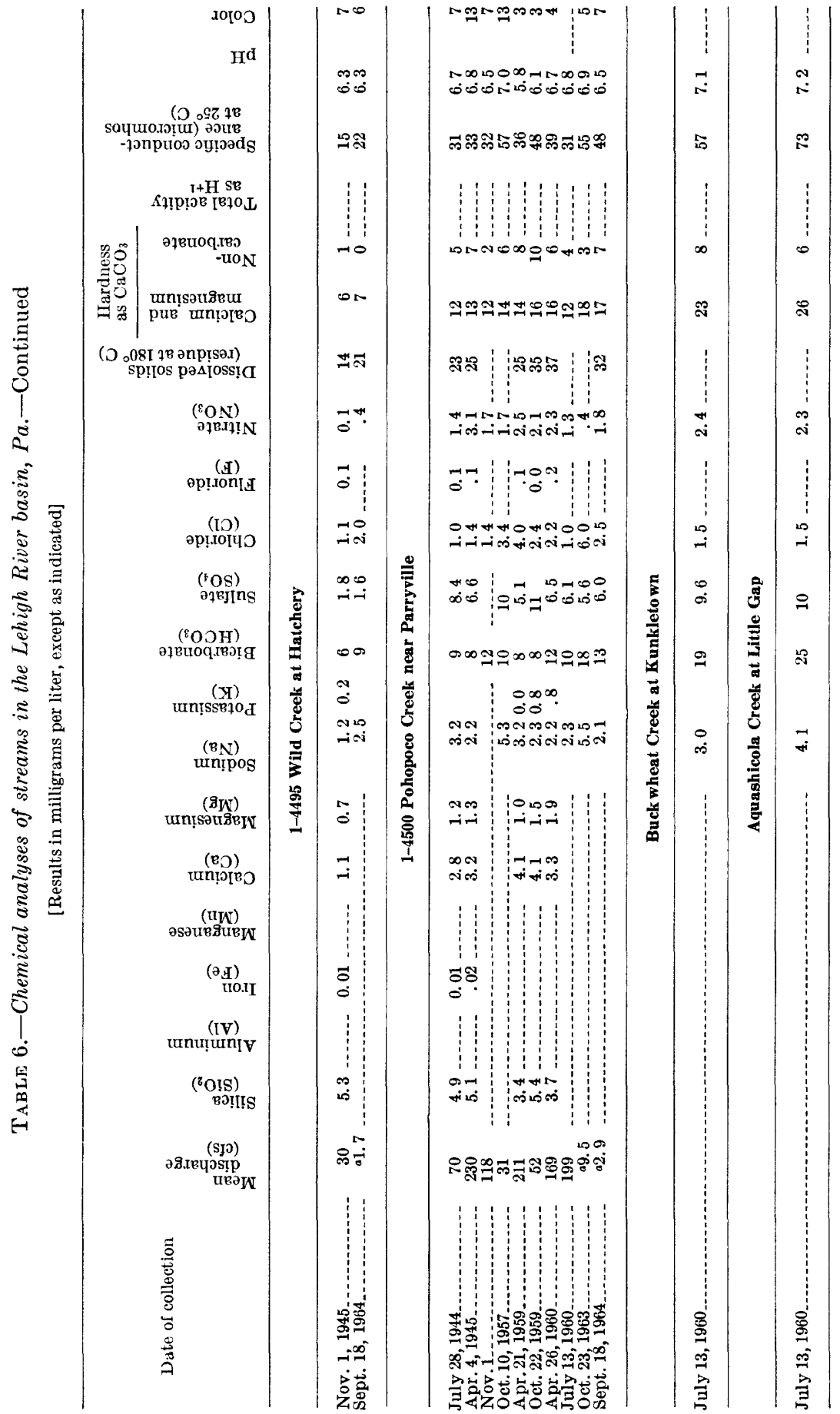




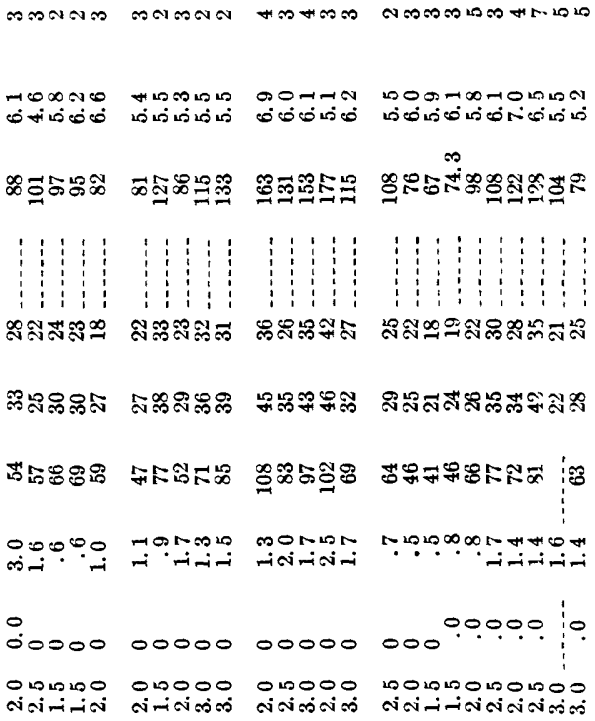




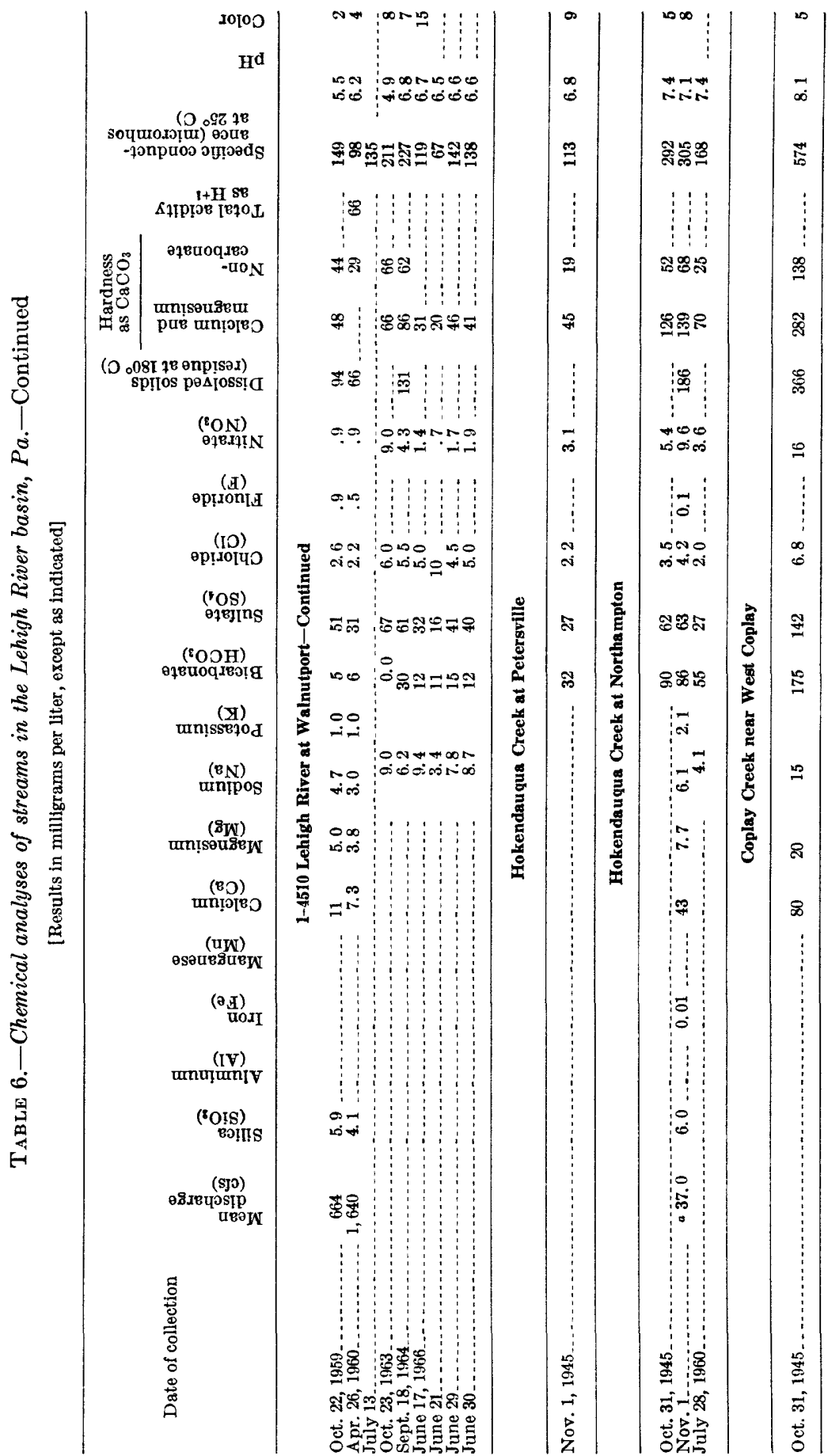




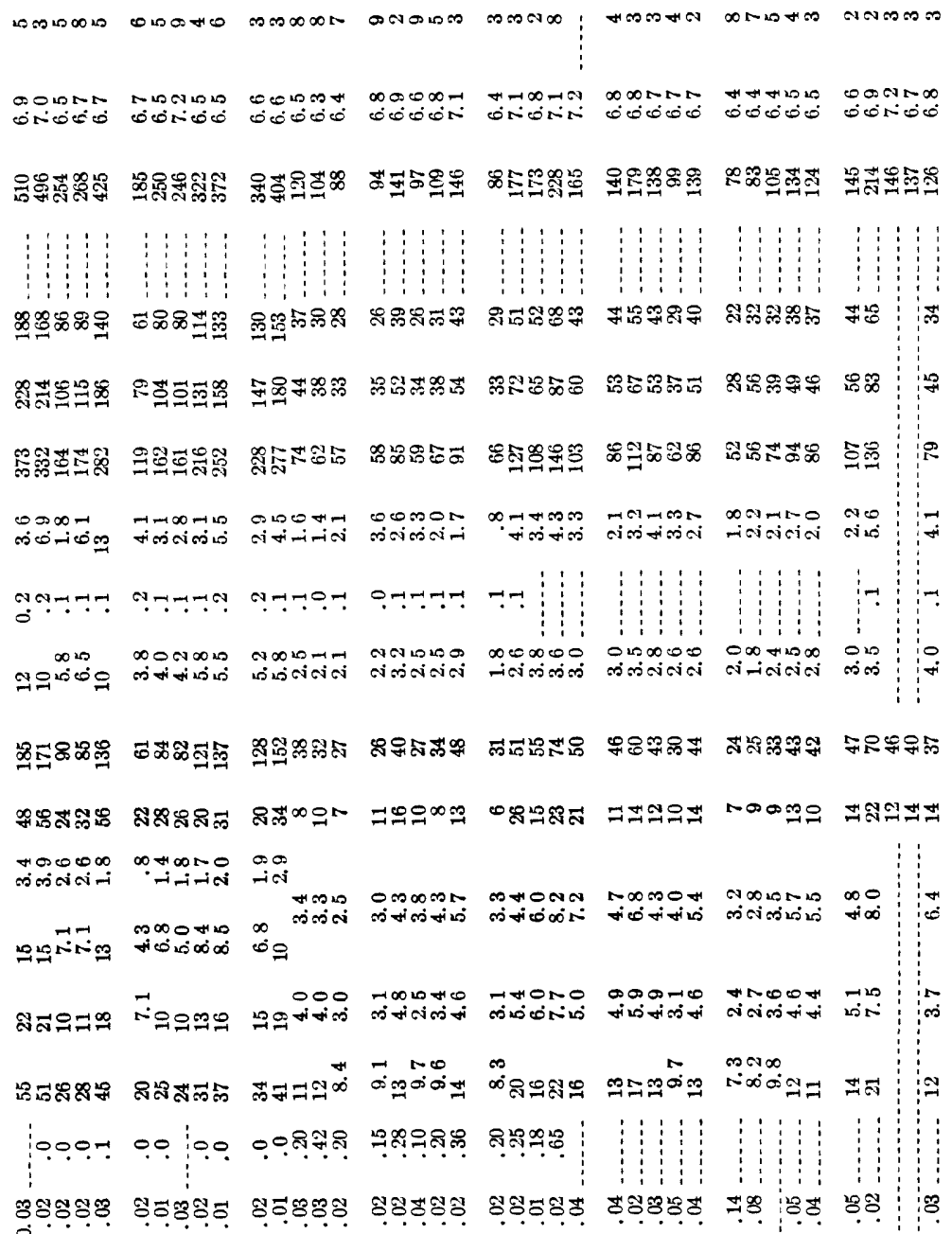

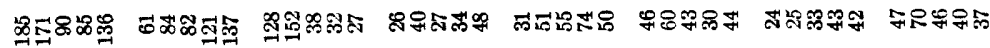

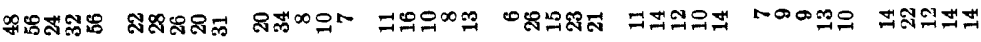

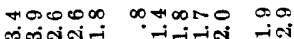

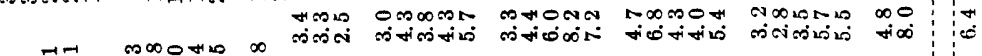

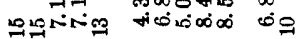

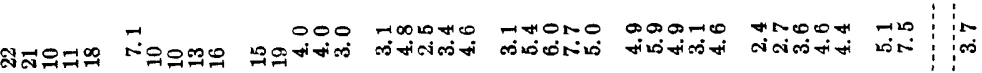

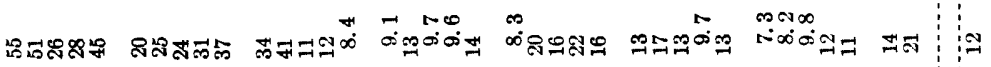

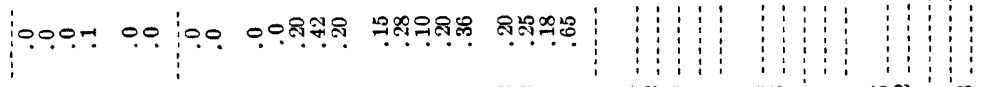

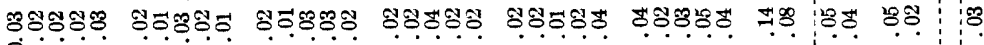
○े

(1)

andano non and

$\infty 0^{\circ} \sin ^{\circ}$

$\pi$ riona

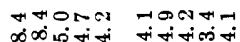

1 11 i :

$\sin 200 \mathrm{Non}$

$0 \pi \operatorname{tas} \infty$

- 0 main

Himion alo

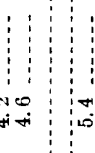

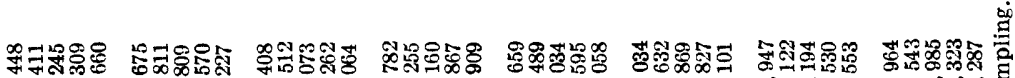
तia nonatifi antion sनinजi-1-i -i बiन sinesin-i in-i g

\section{窎}

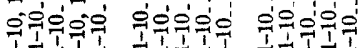

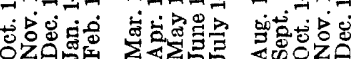

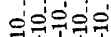

ㅇํํㅇำ IIII IIIII IIIII IIIII IIIII

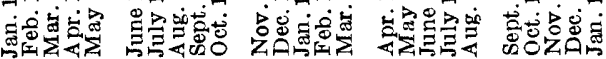




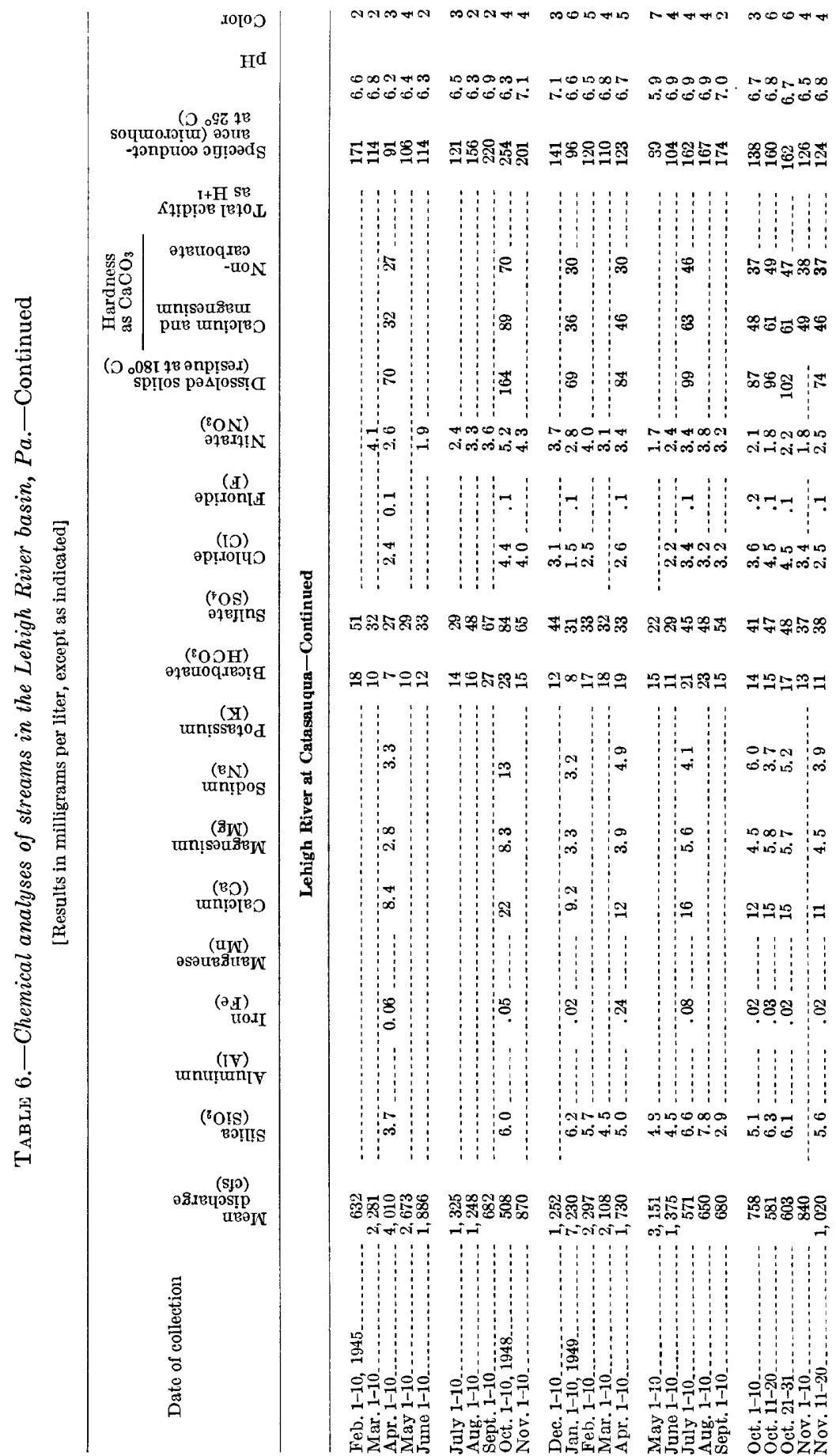




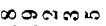
0.0000

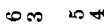

4 o d m n m no

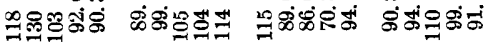

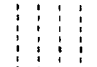

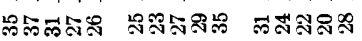

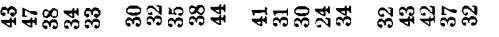

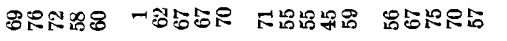$$
\text { oi }
$$$$
\because
$$

\section{कालm}

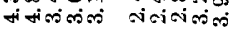

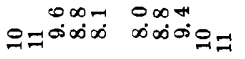

$\operatorname{mos} \pi n$ ต่งก่ง

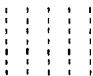

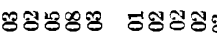

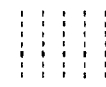

H $20 \infty \mathrm{n}=0$ $20^{\circ} 20^{\circ} 20^{\circ} 25^{\circ} 20^{\circ}$

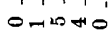

เอ 2000

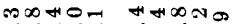

$\infty \infty 0 \infty$
\[ N+\infty \infty \]

$0 \infty \infty \infty$<smiles>[AlH2][V]</smiles>

क्ष

\% 욍동효

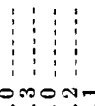

$0 \operatorname{son} n$

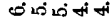

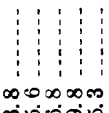

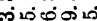

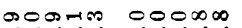
10 $0^{\circ} \times 0^{\circ} 0^{\circ} 0^{\circ}$ mosme manom manth

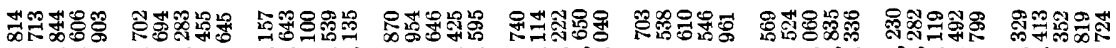

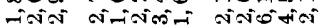 ifinion rifinifi

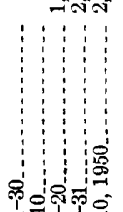

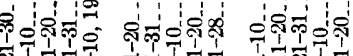

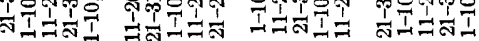

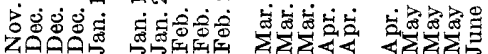 \\ -inis

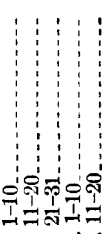

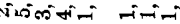




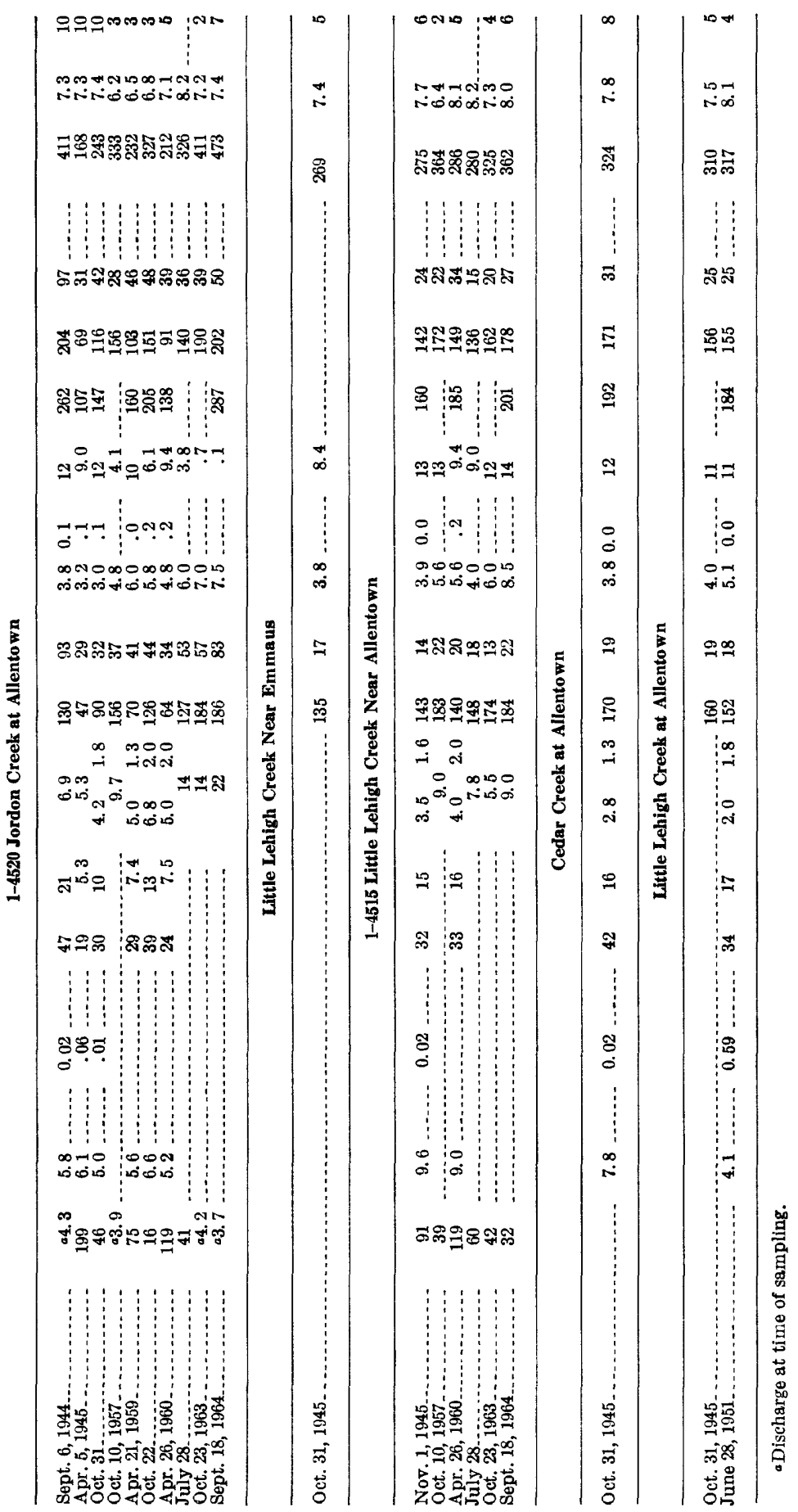




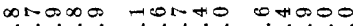

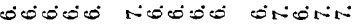

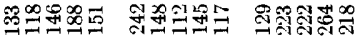

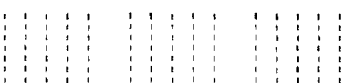

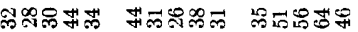

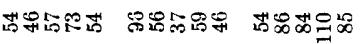

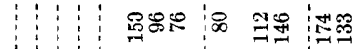

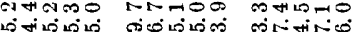

i! i i i

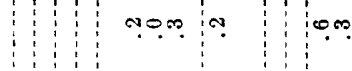

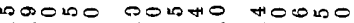

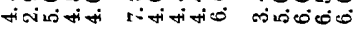

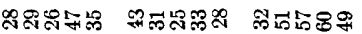

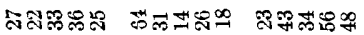

काin

$000+\infty$

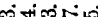

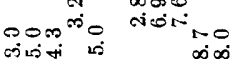

antat

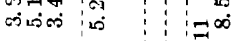

$\begin{array}{l:l}N & \infty \\ N & \infty\end{array}$

ำก

떡요요

5.-88 8

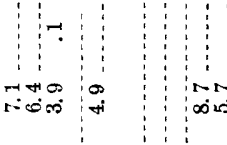

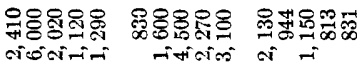

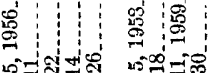

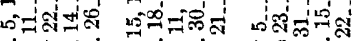

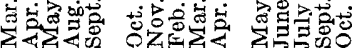




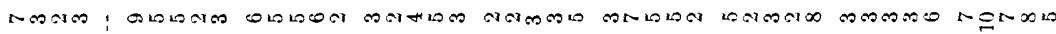

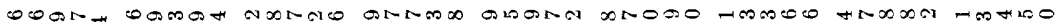

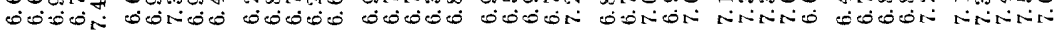

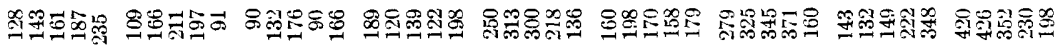

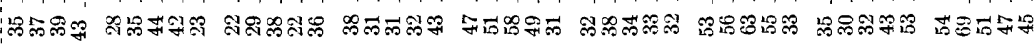

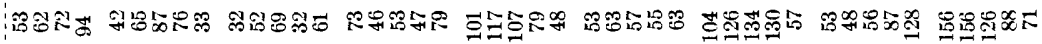

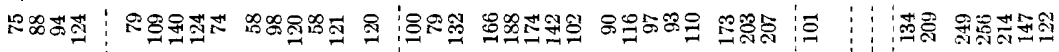

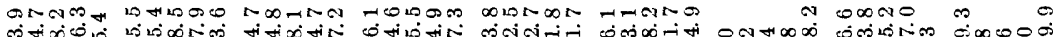
மमंक्ठ

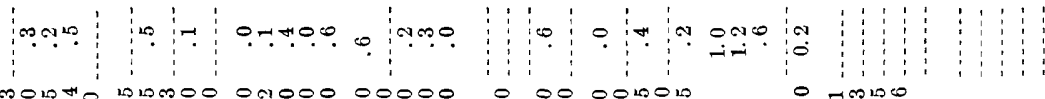

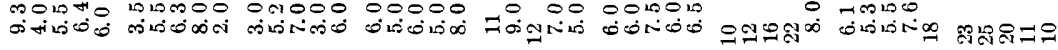

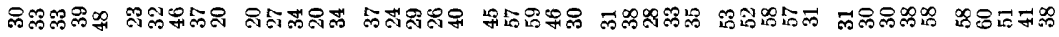

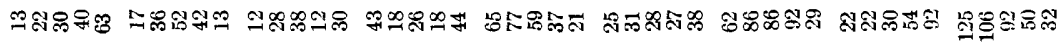

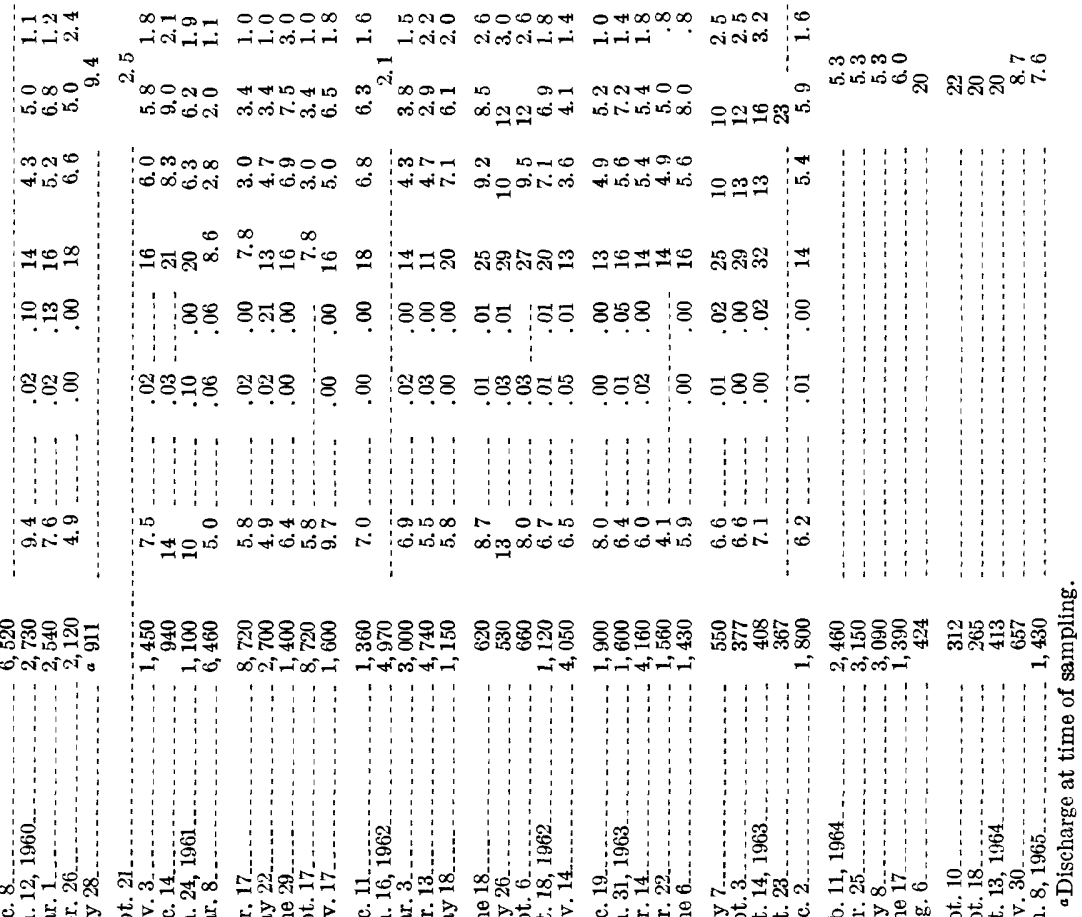

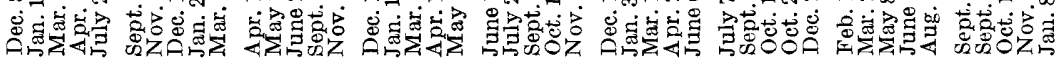




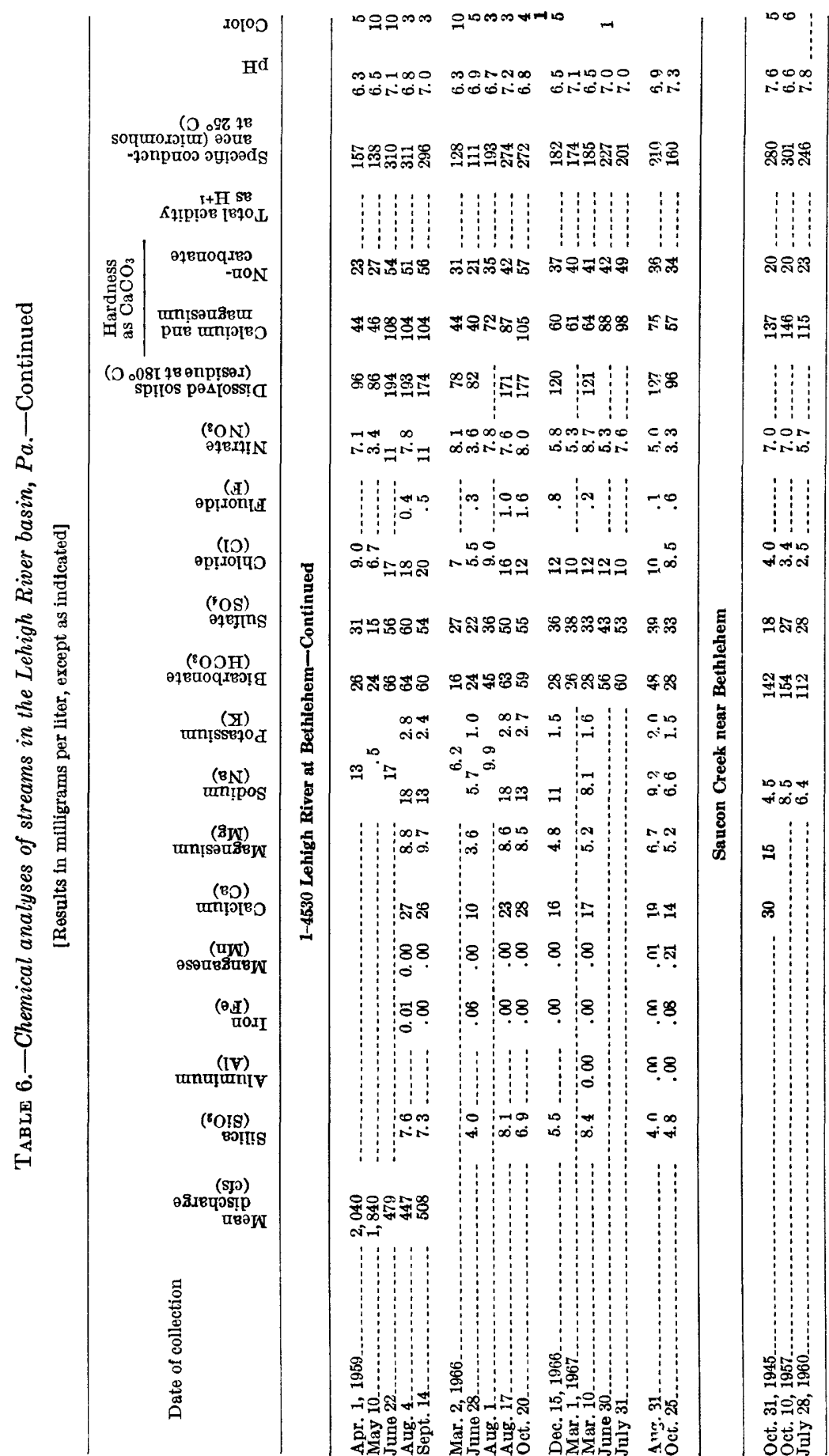


WATER, LEHIGH RIVER BASIN, PENNSYLVANIA

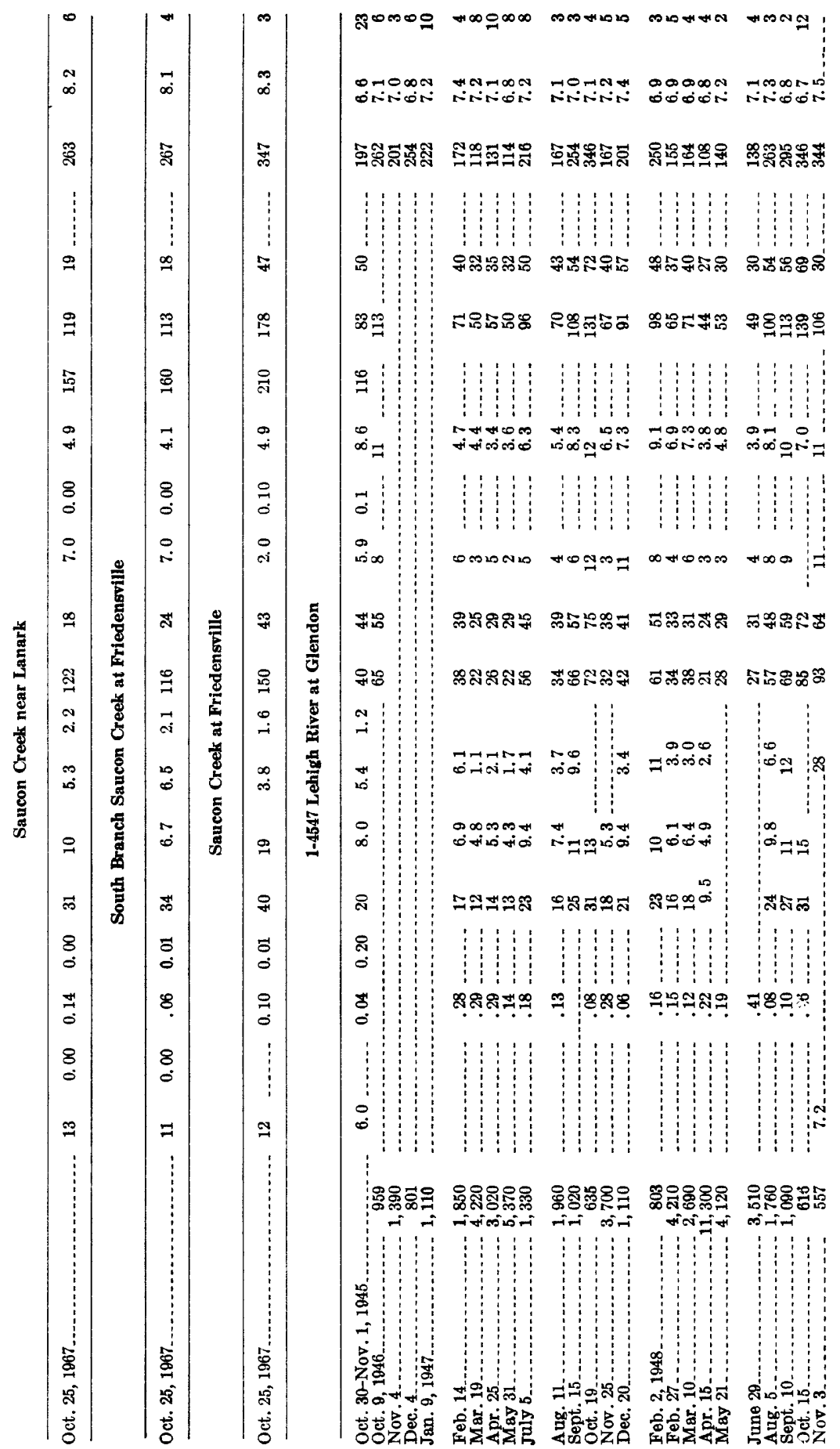




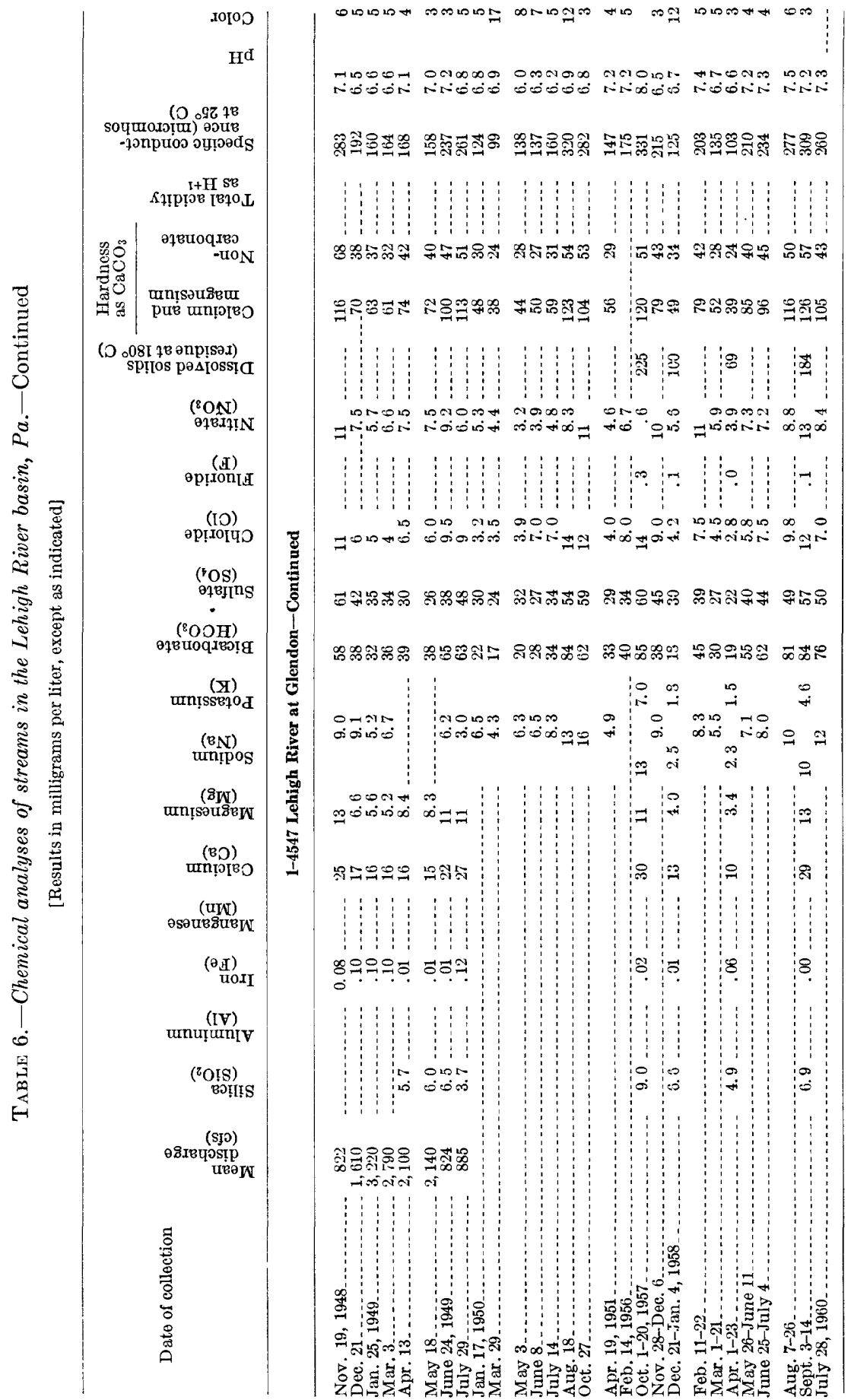




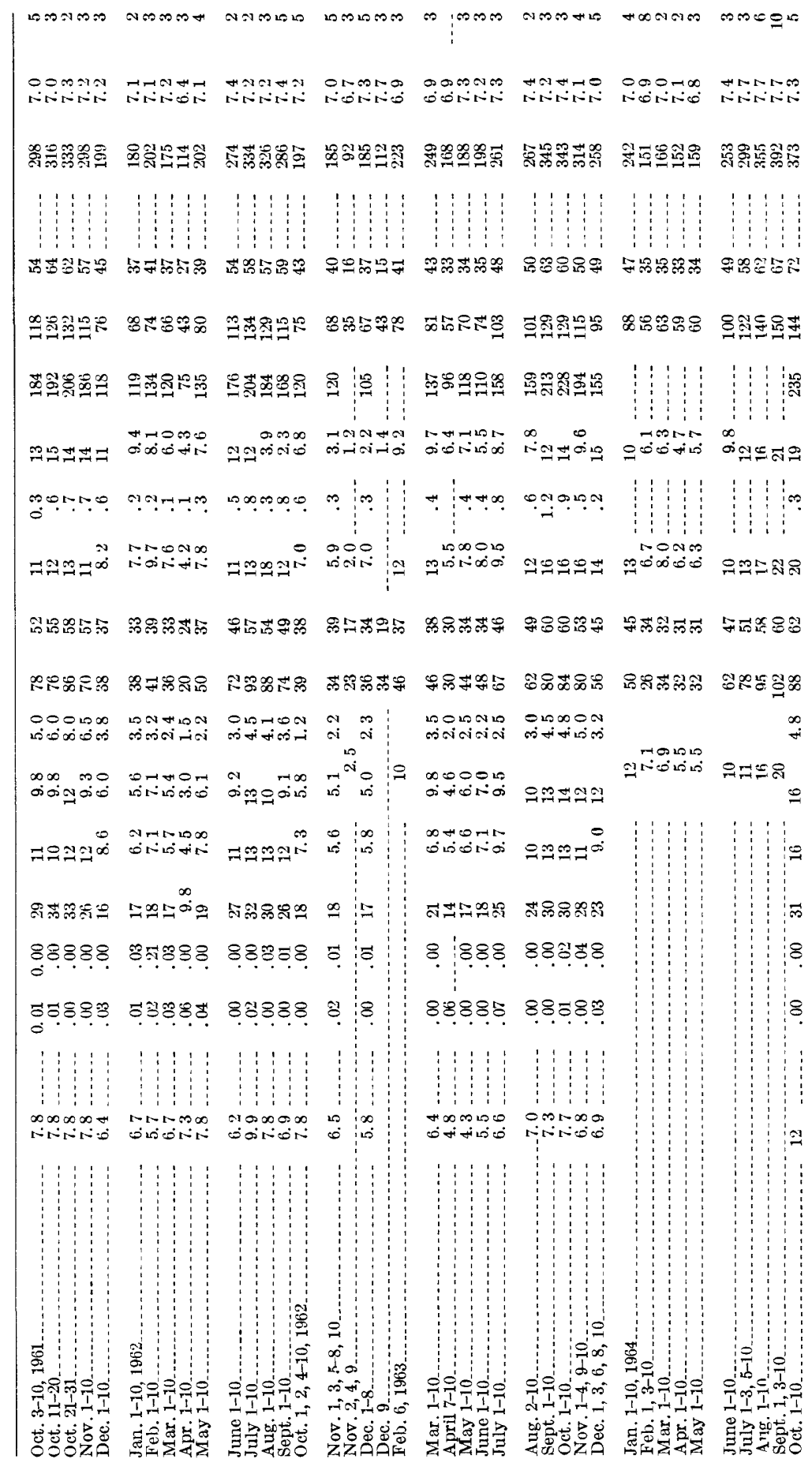




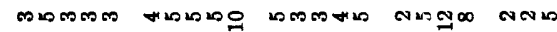

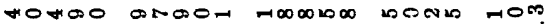

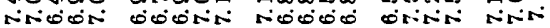

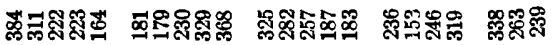

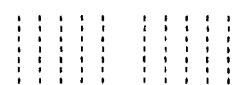

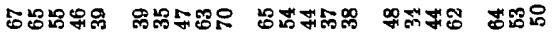

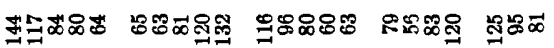

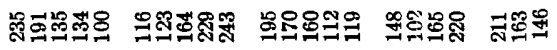

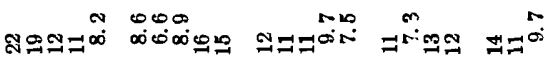

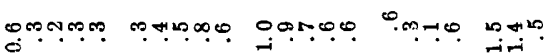

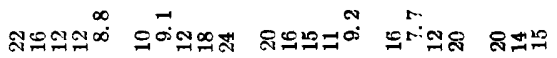

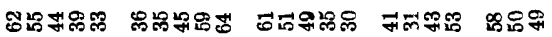

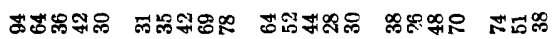

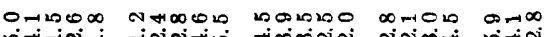

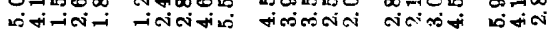

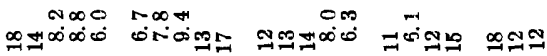

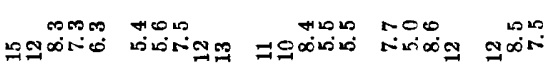

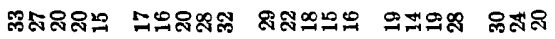

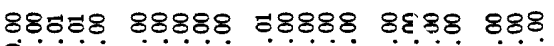
88888 5888. $5888 \%$ 8․ㅇㅇㅛ 8 유. , . 1 1 1

:

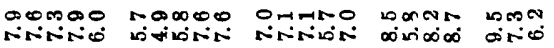

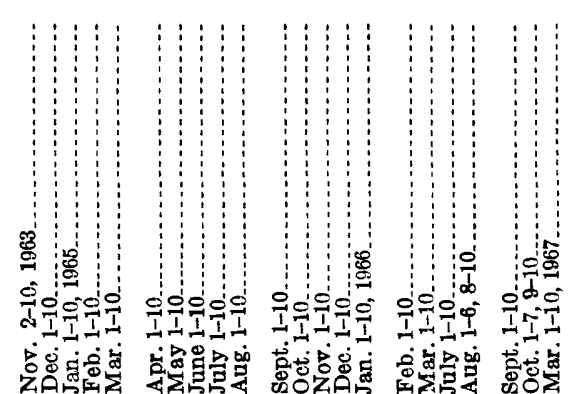




\section{Contributions to the}

Hydrology of the

United States

\section{8}

$\begin{array}{lllll}\text { GEOLOGICAL SURVEY } & \text { WATER-SUPPLY } & \text { PAPER } & 1879\end{array}$

This volume was printed

as separate chapters $A-H$

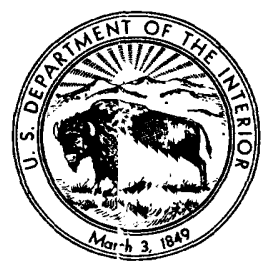


UNITED STATES DEPARTMENT OF THE INTERIOR

WALTER J. HIGKEL, Secretary

GEOLOGIGAL SURVEY

William T. Pecora, Director 


\section{CONTEN'TS}

[Letters designate the separately published chapters]

(A) Water resourees of Clark, Cleveland, and Dallas Counties, Arkansas, by R. O. Plebuch and M. S. Hines.

(B) Water resources of Randolph and Lawrence Counties, Arkansas, by A. G. Lamonds, M. S. Hines, and R. O. Plebuch.

(C) Ground-water aspects of the lower Henrys Fork region, eastern Idaho, by E. G. Crosthwaite, M. J. Mundroff, and E. H. Walker.

(D) Water resources of the Salmon Falls Creek basin, Idaho-Nevada, by E. G. Crosthwaite.

(E) Variations in low-water streambed elevations at selected stream-gaging stations in northwestern California, by J. J. Hickey.

(F) Hydrologic effects of the 1962-66 drought on Long Island, N.Y., by Philip Cohen, O. L. Franke, and N. E. McClymonds.

(G) Dispersal of plating wastes and sewage contaminants in ground water and surface water, South Farmingdale-Massapequa area, Nassau County, New York, by N. M. Perlmutter and Maxim Lieber.

(H) Water quality and discharge of streams in the Lehigh River basin, Pennsylvania, by E. F. McCarren and W. B. Keighton. 